\title{
THE MCCARRAN-FERGUSON ACT'S ANTITRUST EXEMPTION FOR INSURANCE: LANGUAGE, HISTORY AND POLICY
}

\author{
Charles D. Weller*
}

The United States Supreme Court recently decided for the first time a case involving the application of the McCarran-Ferguson Act $^{1}$ to the federal antitrust laws. ${ }^{2}$ In the absence of other high court decisions in this area of the law, numerous significant issues concerning this important antitrust exemption have yet to be authoritatively resolved. During the more than three decades the McCarran-Ferguson Act has been in effect, the lower courts have dealt with many of these issues. New issues continue to be raised as the insurance business responds to new market demands and continues to change its business practices from those that existed at the time the McCarran Act was enacted in 1945.

The Supreme Court has given some indication how it might decide some of the antitrust questions under the McCarran Act through nine previous McCarran Act decisions that arose in other contexts. ${ }^{3}$ For ex-

* Assistant Ohio Attorney General, Antitrust Section. B.A. 1966, Yale University; J.D. 1973, Case Western Reserve University. The views expressed here are not necessarily those of Ohio Attorney General William J. Brown.

THE FOLLOWING CITATIONS WILL BE USED IN THIS ARTICLE:

R. KeEton, Insurance LAw (1971) [hereinafter cited as KeETON];

National association of Insurance Commissioners, Monitoring Competition: A Means of Regulating the Property and Liability InsuranCe Business (1974) [hereinafter cited as NAIC];

Rose, State Regulation of Property and Casualty Insurance Rates, 28 OHI ST. L.J. 669 (1967) [hereinafter cited as Rose].

1. 15 U.S.C. $\$ \$ 1011-1015$ (1976). See Appendix A infra.

2. St. Paul Fire \& Marine Ins. Co. v. Barry, 98 S. Ct. 2923 (1978). The Court recently granted certiorari in another case involving the McCarran Act. Royal Drug Co. v. Group Life \& Health Ins. Co., 556 F.2d 1375 (5th Cir. 1977), cert. granted, 98 S. Ct. 1448 (1978).

3. See SEC v. National Sec., Inc., 393 U.S. 453 (1969); State Bd. of Ins. v. Todd Shipyards Corp., 370 U.S. 451 (1962); FTC v. Travelers Health Ass'n, 362 U.S. 293 (1960); SEC v. Variable Annuity Life Ins. Co., 359 U.S. 65 (1959); FTC v. National Cas. Co., 357 U.S. 560 (1958); Wilburn Boat Co. v. Fireman's Fund Ins. Co., 348 U.S. 310 (1955); Maryland Cas. Co. v. Cushing, 347 U.S. 409 (1954); Robertson v. California, 328 U.S. 440 (1946); Prudential Ins. Co. v. Benjamin, 328 
ample, in three of the four cases where the preemptive effects of state law were specifically involved, the Court construed the Act narrowly so that federal law was not preempted. ${ }^{4}$ The Court's treatment of the McCarran Act, revealing a grudging attitude towards the preemption of federal law by state law, contrasts sharply with the granting by some lower courts of McCarran Act antitrust exemptions. ${ }^{5}$ In a number of these cases it seemed that state insurance regulatory interests could be reconciled with the federal antitrust laws. Indeed, the lower courts' treatment of the McCarran Act antitrust exemption in some respects bears a striking resemblance to the manner in which lower courts applied the Parker v. Brown ${ }^{6}$ state action exemption from 1943 until the Supreme Court's decisions in Goldfarb v. Virginia State Bar ${ }^{7}$ and Cantor v. Detroit Edison Co.8:

Cantor and Goldfarb demonstrate beyond serious questioning that the Supreme Court is not inclined any longer, if it ever was, to accept superficial and mechanical application of a Parker-based "rule" that antitrust inquiry ends upon such a finding of governmental actions or laws being involved. In the years after Parker and before Goldfarb and Cantor, there was a tendency in many of the reported decisions to apply Parker broadly and to use rather general language in so doing. . . . We point out, however, that Goldfarb and Cantor undercut the validity of any such simple one-sentence "rule" as a general proposition.?

The Supreme Court's treatment of the closely analogous Parker doctrine could have very important implications for the antitrust immunity provided by the McCarran Act. The Parker doctrine deals generally with the extent to which state regulation of business can provide antitrust immunity; the McCarran Act deals with the same issue in the context of the insurance business. Indeed, it will be seen that there is strong support for the proposition that the McCarran Act essentially codifies the Parker doctrine as it affects the insurance business. ${ }^{10}$

Some commentators have urged that the McCarran Act should be legislatively modified or even repealed. ${ }^{11}$ This Article instead explores

U.S. 408 (1946); cf. SEC v. United Benefit Life Ins. Co., 387 U.S. 202 (1967) (construing the Variable Annuity decision in a non-McCarran Act case).

4. See SEC v. National Sec., Inc., 393 U.S. 453 (1969); FTC v. Travelers Health Ass'n, 362 U.S. 293 (1960); SEC v. Variable Annuity Life Ins. Co., 359 U.S. 65 (1959). FTC v. National Cas. Co., 357 U.S. 560 (1958), was the one case where the Court did not so hold.

5. See text accompanying notes 106-27 infra.

6. 317 U.S. 341 (1943).

7. 421 U.S. 773 (1975).

8. 428 U.S. 579 (1976).

9. Kurek v. Pleasure Driveway \& Park Dist., 557 F.2d 580, 589 (7th Cir. 1977).

10. See text accompanying notes $132-54$ infra.

11. See, e.g., U.S. Dept. of Justice, The Pricing and Marketing of Insurance (Jan. 
some of the many issues remaining to be resolved by the Supreme Court on the scope of the McCarran-Ferguson antitrust exemption ${ }^{12}$ and argues that the interpretation of the exemption needs tightening. In particular, the Article provides an in-depth analysis of the genesis and legislative history of the Act, revealing a fundamentally federalist purpose of accommodating both federal and state authority. A two-stage test consistent with this purpose is developed for section 2(b), including consideration of the Parker doctrine and a critique of lower court decisions that deviate from legislative intentions. Finally, the Article addresses the question of whether McCarran Act antitrust immunity should be extended to inter-industry restraints of trade.

\section{Genesis of the McCarran-Ferguson Act: The SOUTH-EASTERN UNDERWRITERS LITIGATION}

The basic facts surrounding the enactment of the McCarran Act are well known. ${ }^{13}$ For over seventy-five years, state insurance departments had exercised a free hand in regulating the dealings between insurers and their policyholders. In the leading case, Paul v. Virginia ${ }^{14}$ Supreme Court dictum that "[i] ssuing a policy of insurance is not a transaction of commerce"15 was considered by many to mean that the federal government had no authority over the insurance industry under the commerce clause. Every state had an insurance department in-

1977); Note, The McCarran-Ferguson Act: A Time for Procompetitive Reform, 29 VAND. L. REv. 1271 (1976). The Federal Insurance Act of 1977, S. 1710, 95th Cong., 1st Sess. (1977), is presently before Congress.

12. This Article does not consider several issues raised by the Supreme Court's decision in FTC v. Travelers Health Ass'n, 362 U.S. 293 (1960), which held that state regulation cannot provide immunity for practices with an extraterritorial impact. Also not discussed is the interesting issue of whether the McCarran-Ferguson Act, which was enacted to preserve regulation by state insurance departments, applies when a different state agency or official does the regulating. See, e.g., Manasen v. California Dental Serv., 424 F. Supp. 657 (N.D. Cal. 1976) (McCarran-Ferguson Act does apply to regulation by the state attorney general).

The important question of whether state antitrust laws were intended to trigger McCarran Act immunity from the federal antitrust laws is analyzed and answered in the negative in Weller, To Preempt or To Accommodate: The Question of State and Federal Antitrust Laws Under the McCarran Ferguson Act, 9 Tol. L. Rev. 421 (1978).

The issue of whether insurance is even involved in certain cases, raised by SEC v. Variable Annuity Life Ins. Co., 359 U.S. 65 (1959), is discussed at note 174 infra.

13. See generally SEC v. National Sec., Inc., 393 U.S. 453, 458-59 (1969); J. DAY, Economic Regulation of INSURANCE IN THE UNITEd STATES (U.S. Dep't of Transp. 1970); NAIC 21-22; Mertz, The First Twenty Years-A Case-Law Commentary on Insurance Regulation Under the Commerce Clause, 1964 ABA Proc., Section of Ins., Negligence \& Compensation L. 153, 153-58; Rose 682-89; Wiley, Pups, Plants and Package Policies-or the Insurance Antitrust Exemption Reexamined, 6 VILL. L. REv. 281, 288-91 (1961).

14. 75 U.S. (8 Wall.) 168 (1868).

15. Id. at 183 . 
volved in regulating the insurance business, although the scope of regulation varied from state to state. ${ }^{16}$

In November 1942, the Antitrust Division of the U.S. Department of Justice obtained a criminal indictment in Georgia against the SouthEastern Underwriters Association, twenty-seven of its officers and 198 member companies. ${ }^{17}$ The Supreme Court in its landmark decision of United States v. South-Eastern Underwriters Association (S.E.U.A.) ${ }^{18}$ reversed the district court's dismissal of the indictment and held, first, that the insurance industry was subject to federal regulation under the commerce clause and, second, that the Sherman Act applied to the insurance industry as well. ${ }^{19}$

The Court's ruling generated a flood of often torrid commentary. As one observer noted: "The decision precipitated widespread controversy and dismay. Chaos was freely predicted." 20 Three themes were frequently expressed and greatly influenced congressional response to the S.E.U.A. decision. The first contention was that of the S.E.U.A. defendants and others in the fire insurance industry who felt the threat of criminal prosecution most immediately. They argued that the antitrust laws were wholly inappropriate for their industry and that wholesale legislative immunity was necessary. ${ }^{21}$ Second, there was serious concern that state tax and regulatory schemes would now be found unconstitutional under the commerce clause.

The decision had a devastating impact upon the entire system of state regulation built up, through trial and error, over a period of more than seventy-five years.

The validity of every state statute, court decision, and departmental ruling relating to regulation or taxation of insurance became immediately questionable. ${ }^{22}$

16. See generally 90 Cong. REC. A4403-04 (1944); J. DAY, supra note 13, at 1-23; E. PATterson, The Insurance Commissioner in the United States \& 19 (1927); Brook, Public Interest and the Commissioners-All Industry Laws, 15 LAW \& ConTEMP. PROB. 606 (1950).

17. The indictment resulted from a Justice Department investigation prompted by the Attorney General of Missouri, who felt powerless to deal effectively with abuses that state officials had been trying to correct since 1922. Rose 683.

18. 322 U.S. 533 (1944).

19. On the same day, the Court unanimously reiterated the first proposition regarding the commerce clause in a case involving the NLRA. Polish Nat'1 Alliance v. NLRB, 322 U.S. 643,649 (1944).

20. New York INSURANCE DePARTMENT RePORT 71 (1969), quoted in NAIC 23.

21. See, e.g., Joint Hearings on S. 1362, H.R. 3269, and H.R 3270 Before the Subcomms. of the Comms. on the Judiciary, 78th Cong., 1st \& 2d Sess. 73, 259, 421, 526 (1943) (remarks of E. Williams).

22. E. SAWyer, Insurance as Interstate Commerce 50-51 (1945). 
This concern was directly supported by dissenting justices in the S.E.U.A. decision. Mr. Justice Jackson's dissent expressly suggested that state tax and regulatory schemes were probably unconstitutional. ${ }^{23}$ Chief Justice Stone foresaw "a flood of litigation and of legislation" that would take years to resolve, ${ }^{24}$ in fact, within one year of the S.E.U.A. decision, court actions challenging tax laws in eleven states had been filed, and taxes were paid under protest in thirty-one states. ${ }^{25}$ Ultimately, state regulation and taxation of insurance were upheld by the courts, ${ }^{26}$ but their constitutionality was a matter of real concern at the time of the S.E.U.A. litigation.

The third theme of the commentary provoked by the S.E.U.A. decision was that the activist Roosevelt administration was determined to federalize insurance regulation and to displace the states' role. Mr. Justice Jackson noted this development in his dissent in S.E.U.A.: "I have little doubt that if the present trend continues federal regulation eventually will supersede that of the states."27 The classic statement of this concern came from Senator Ferguson in an address to state insurance commissioners in 1946:

There is a domination today by the bureaucracy and there were a few people, I am satisfied, in Washington that were licking their chops when they knew that the United States Supreme Court declared that the insurance business of America was interstate commerce. What a great bureau could be built if we had them all down in Washington regulating the insurance business of America and putting out of business these 48 Commissioners here! ${ }^{28}$

The fear of a federal takeover of state insurance department regulation was real and was one of the important issues addressed by the McCar-

23. The Court's decision at very least will require an extensive overhauling of state legislation relating to taxation and supervision. The whole legal basis will have to be reconsidered. What will be irretrievably lost and what may be salvaged no one now can say, and it will take a generation of litigation to determine. Certainly the states lose very important controls and very considerable revenues.

S.E.U.A., 322 U.S. at 590 (Jackson, J., dissenting in part).

24. Id. at 583 (Stone, C. J., dissenting). Generally lost in the furor were the pertinent portions of Mr. Justice Black's majority opinion, which to the contrary suggested that state taxation and regulation would not be held unconstitutional. Id. at 548.

25. Insurance Field (Life ed.), May 25, 1944, at 17-20. See also the editions for March 16, 1945, at 3 and March 23, 1945, at 3.

26. See, e.g., Robertson v. California, 328 U.S. 440 (1946); Prudential Ins. Co. v. Benjamin, 328 U.S. 408 (1946); Mendola v. Dineen, 185 Misc. 540, 57 N.Y.S.2d 219 (Sup. Ct. 1945). But see State Bd. of Ins. v. Todd Shipyards Corp., 370 U.S. 451 (1962) (Texas five-percent gross premium tax invalid as applied to unlicensed insurer that did no more than insure risks located in Texas). See generally California State Auto. Ass'n Inter-Ins. Bureau v. Maloney, 341 U.S. 105, 109 n.2 (1951); Mertz, supra note 13, at 180-87.

27. 322 U.S. at 586 (Jackson, J., dissenting in part).

28. 1947 NAIC Proc. 69, 74 (address of Sen. Ferguson, Dec. 11, 1946). 
ran-Ferguson Act. ${ }^{29}$

Congressional reaction to the S.E.U.A. litigation began even before the Supreme Court's decision. In October 1943, Congress began hearings on several bills that would have provided a complete exemption for the insurance industry from the Sherman and Clayton Acts. The total-exemption approach, however, was rejected, and Congress ultimately adopted the fundamentally different approach proposed by the National Association of Insurance Commissioners (NAIC). ${ }^{30}$

\section{A. The Initial Attempt at Total Exemption.}

The complete-exemption bills were sponsored by the stock insurance companies who were most directly affected by the S.E.U.A. litigation. Several total-exemption bills were introduced, ${ }^{31}$ and on June 22, 1943, just seventeen days after the Supreme Court announced its S.E.U.A. decision, the House passed the Walter-Hancock bill, H.R. $3270 .{ }^{32}$ The Senate, however, did not act as quickly or as favorably as the House. The fate of the total-exemption bills was largely decided on September 21, 1944, when the Senate first passed, then reconsidered and rejected the Walter-Hancock bill. ${ }^{33}$ Although strenuous efforts were made to pass some form of legislation before the end of the session in December, they were all unavailing. ${ }^{34}$

29. See Kimball \& Boyce, The Adequacy of State Insurance Rate Regulation: The McCarran. Ferguson Act in Historical Perspective, 56 Mich. L. REv. 545, 553-55 (1958).

30. See text accompanying notes 35-59 infra.

31. Some of the bills ultimately considered by Congress on the subject were H.R. 3269, 78th Cong., 1st Sess. (1943); H.R. 3270, 78th Cong., 1st Sess. (1943); H.R. 4444, 78th Cong., 2d Sess. (1944); S.1362, 78th Cong., 1st Sess. (1943); H.R. 1207, 79th Cong., 1st Sess. (1945); H.R. 1590, 79th Cong. 1st Sess. (1945); H.R. 1973, 79th Cong. 1st Sess. (1945); H.R. 2021, 79th Cong., 1st Sess. (1945); S. 12, 79th Cong., 1st Sess. (1945); and S. 340, 79th Cong., 1st Sess. (1945), reprinted at Appendix B infra. In addition, Edward Stone, who represented stock casualty interests, vigorously argued the need for a constitutional amendment as the only adequate means of reversing the S.E.U.A. decision. 151 WeEKLY UNDERWRITER 953 (Oct. 28, 1944).

32. 90 CoNG. Rec. 6565 (1944).

33. Id. 8054.

34. There were several important reasons why the complete-exemption bills failed. See generally Rose 693. Probably the most significant was the clear threat of President Roosevelt's veto. "Observers had long predicted that President Roosevelt would veto the Balley-Walter Bill in its original form since it would take insurance out from under the Sherman and Clayton Acts entirely." Spectator Property Ins. Rev., Jan. 11, 1945, at 5; see 91 Cong. Rec. 1087 (1945) (remarks of Rep. Hancock). See also National Underwriter (Life ed.), Sept. 22, 1944, at 1. See note 59 infra.

Another important reason the blanket exemption bills failed to pass Congress was that only a small segment of the insurance community supported the bills. The state insurance commissioners, represented by the NAIC, never supported the bills and opposed the concept of total exemption from the federal antitrust laws: "The Commissioners believe that the insurance business has no more right to ask for a blanket exclusion from those acts than has any other business that has been held to be engaged in interstate commerce." Letter from Michigan Insurance Commissioner 


\section{B. The Emergence of the State Commissioners' Approach.}

Congress next considered the NAIC's approach to the issues raised by the S.E.U.A. litigation. It was the "Comissioners' Bill," as the NAIC's fundamentally different proposal came to be called, that was ultimately adopted by Congress as the McCarran-Ferguson Act. For this reason, the details of its genesis are particularly germane.

Obviously, the NAIC's motivations were entirely different from those of the stock insurance companies responding to the immediacy of Sherman Act indictments. The insurance commissioners were essentially interested in preserving state regulation of insurance, not in eliminating the applicability of the federal antitrust laws:

The decision of the United States Supreme Court in the SouthEastern Underwriters case confronted Congress, the State Legislatures and the Insurance Commissioners with a problem-the task of preserving state regulation and at the same time not emasculating the federal anti-trust laws. ${ }^{35}$

Soon after the Supreme Court's S.E.U.A. decision on June 5, 1944, NAIC President and Massachusetts Commissioner C.F.J. Harrington urged the NAIC to disregard the blanket-exemption bills and to draft its own bill. ${ }^{36}$

The first concrete indication of the NAIC's approach appeared as a Report of the NAIC Subcommittee on Federal Legislation released in

David Forbes to Senator Vandenberg (Nov. 22, 1944), reprinted in 90 CoNG. Rec. 8482 (1944). The life and mutual companies did not back the total-exemption bills either and supported instead the NAIC approach. Insurance Field (Life ed.), Dec. 18, 1944, at 4, 20-21. See also Insurance Field (Life ed.), Aug. 25, 1944, at 3, and Nov. 17, 1944, at 3 ("Life insurance interests have never supported the [total-exemption] bill"). The life companies simply did not feel threatened by the Sherman Act. This confidence was displayed in the conclusions of Powell Haney, vice president and general counsel of General American Life: "[A]fter a review of the practices of life insurance companies, I have no hesitation in stating that the application of the Sherman Anti-trust Law to the life insurance business will occasion no great inconvenience." Insurance Field (Life ed.), Oct. 27, 1944, at 6-7. The Life Insurance Association of America, not surprisingly, expressly stated its opposition to the complete-immunity bills. Insurance Field (Life ed.), Dec. 8, 1944, at 20-21. The fact that the total-exemption-type bills were special interest legislation for the stock fire and casualty companies who wanted to legislatively nullify the S.E.U.A. decision was also debated before Congress. See, e.g., H.R. REP. 873, 78th Cong., 1st Sess. 1 (1943); Joint Hearings, supra note 21, pt.1, 24 (remarks of Attorney General Biddle); 89 CoNG. REC. A5683-90 (1943) (remarks of Rep. LaFollette).

Finally, Senator O'Mahoney played a key role in killing the blanket-exemption bills. Wiley, supra note 13, at 290 n.30. See also 91 CoNG. Rec. 1484 (1945) (remarks of Sen. Murdock); id. 1487 (remarks of Sen. Barkley). He argued forcefully that Congress should not act until the views of the state insurance commissioners and the NAIC had been heard. S. REP. No. 1112, 78th Cong., 2d Sess., Pt. 2, at 6 (minority report).

35. 1945 NAIC PROC. 156, 159-60 (interim report of the Subcomm. on Fed. Legis.) (emphasis added). This NAIC policy of accommodating both state regulation and federal law is manifest in the Commissioners' Bill itself.

36. Insurance Field (Life ed.), June 16, 1944, at 3. 
St. Louis on August 29, 1944. The Report recommended that legislation cover four basic points: (1) a commerce clause declaration by Congress in favor of the continued taxation and regulation of insurance by the states; (2) complete exemption of insurance from the Federal Trade Commission (FTC) Act; (3) complete exemption of insurance from the Robinson-Patman Act; and (4) limited exemption of insurance from the Sherman and Clayton Acts for cooperative procedures related to statistics, rates, coverage and similar matters. ${ }^{37}$

Pressure to develop a specific legislative proposal was heightened when the Supreme Court on October 9 denied the petition for rehearing in the S.E.U.A. case. ${ }^{38}$ The first version of the Commissioners' Bill was formally released on November 16, 1944 in Chicago, along with a Memorandum of Explanation and press release. ${ }^{39}$ The Commissioners' Bill consisted of seven sections consistent with the NAIC's Report of August 29, 1944. The first two sections were designed to assure the constitutionality of the state tax and regulatory laws in face of the new threat from the commerce clause, with the first section declaring congressional policy to be in favor of continued state taxation and regulation of insurance. Section 2(a) made the business of insurance subject to state tax and regulatory laws, and section 2(b) provided generally that federal law should not "invalidate, impair, or supersede" state insurance laws. Section 3 exempted insurance from the FTC and Robinson-Patman Acts, while section 4 set forth a limited exemption from what the NAIC termed the "non-regulatory" Sherman and Clayton Acts. Section 4(a) provided a temporary moratorium until July 1, 1948 during which the Sherman and Clayton Acts would not apply, and section 4(b) exempted seven specific cooperative activities relating to insurance rate making, forms, adjustments, investigations, reinsurance, commissions and statistics from the Sherman Act. Section 4(c) expressly made the Sherman Act applicable to any act of boycott, coercion and intimidation. Section 5 effectively codified Polish National Alliance v. $N L R B^{40}$ by providing that the National Labor Relations Act and the Fair Labor Standards Act applied to insurance. Section 6 defined the term "state," and section 7 contained the usual separability clause. ${ }^{41}$

37. 1945 NAIC PROc. 23, 28-29, reprinted in 90 CoNG. REC. A4403-05 (1944).

38. 323 U.S. 811 (1944).

39. 1945 NAIC Proc. 32-40, reprinted in 90 CoNG. ReC. A4406-08 (1944). See also Insurance Field (Life ed.), Nov. 17, 1944, at 3.

40. 322 U.S. 643 (1944).

41. The text of the proposal is in 1945 NAIC Proc. 32-34, reprinted in 90 CONO. REC. A4406 (1944). 
The NAIC bill was properly seen as "an entirely new bill" 42 by the proponents of the Walter-Hancock bill, who had not yet given up. Thus, the appearance of the NAIC bill sparked a vigorous competition over which approach would prevail. ${ }^{43}$ As one trade journal reported at the time:

There was great activity this week [November 24] as the forces behind each of the insurance bills prepared for Congressional action and debate. Arraigned on the side of the Walter-Hancock bill . . . are the stock fire and casualty insurance companies, and the stock fire and casualty producer organizations [agents and brokers]. Supporting the second bill, now known as the commissioners' bill, . . . are the National Association of Insurance Commissioners, the entire life insurance industry, including fraternals, and the mutual casualty insurance companies. ${ }^{44}$

A day-by-day account of the energetic efforts by NAIC representatives to obtain a compromise among all interested parties and to get a law passed by the end of the year appears in the NAIC Proceedings. ${ }^{45}$ These efforts were directed at the various factions within the insurance industry, at the Roosevelt administration and at such key legislators as Senators O'Mahoney, Ferguson, McCarran and Bailey, and House Leader McCormack.

\section{The Push to Pass the Commissioners' Bill.}

On December 19, 1944, in a major change in position, Senators Ferguson and McCarran introduced an amended version of the Commissioners' Bill as a substitute for the total-exemption bills for which they had worked so long and hard. ${ }^{46}$ The coup de grace was thereby applied to the total-exemption bills, and the NAIC approach prevailed in the internecine battle within the insurance industry.

A new Congress convened in January, and Senators Ferguson and McCarran introduced their amended version of the Commissioners'

42. 151 WEEKLY UNDERWRITER 1117 (Nov. 18, 1944).

43. On November 14, 1944, the fire, casualty and marine insurance agents, brokers and companies stated their unwillingness to compromise on a bill that did not provide outright exemption. 151 WEEKLY UNDERWRITER 1117 (Nov. 18, 1944). The only amendments to which they would have agreed would have added the Federal Trade Commission Act, the Robinson-Patman Act and other federal legislation to the list of exemptions. Id.

44. Insurance Field (Life ed.), Nov. 24, 1944, at 3, 22. There was widespread disagreement in the insurance industry and even among state insurance commissioners as to how to respond to the S.E.U.A. litigation. 1945 NAIC PROC. 144-46; see E. SAWYER, supra note 22, at 3, 54-57, 135-37 (1945). Such fundamental disagreement was not unusual in the insurance field. See, e.g., J. DAY, supra note 13.

45. 1945 NAIC Proc. 139-43, 161-67.

46. McFall, A Calendar of the S.E.U.A. Case, 265 Ins. L.J. 72, 73 (1945). 
Bill as S. $340{ }^{47}$ The key antitrust amendment in their bill was to delete the list of specific exempt activities and to have the Sherman and Clayton Acts governed by the "invalidate, impair, or supersede" standard of section 2(b).

The Senate acted quickly on S. 340. On January 25, one week after the bill had been introduced, the bill was reported to the Senate, debated and passed with two amendments. ${ }^{48}$ The first amendment was to the boycott provision, section 4(b), to make it cover agreements as well as acts of boycott, coercion and intimidation. This amendment had been recommended in the Senate Judiciary Committee's report and did not generate much debate. It was the second amendment, concerning section 2(b), that preoccupied the Senate: should states be permitted to keep or pass laws that conflicted with the Sherman and Clayton Acts? Senators Ferguson and others argued that the states should be permitted to regulate insurance inconsistently with the antitrust laws and that section 2(b) should be left unchanged to include the Sherman and Clayton Acts. In this way, those Acts could not be construed to "invalidate, impair, or supersede" state rating bureau legislation or other conflicting state laws. ${ }^{49}$ Senators O'Mahoney, Murdock and Taft argued to the contrary, maintaining that the states must adjust their insurance laws to conform to the antitrust laws during the moratorium period. As Senator Taft succinctly stated: "We wish [the states] to put their houses in order by adopting laws which do not conflict with the Sherman Act." 50 Later in the debates, Senator Ferguson changed his position and offered an amendment to delete the Sherman and Clayton Acts from the scope of section 2(b). ${ }^{51}$ With these two amendments, S. 340 passed the Senate the same day. ${ }^{52}$

The House rejected both the Ferguson amendment deleting the Sherman and Clayton Acts from section 2(b $)^{53}$ and the amendment to

47. S. 340, 79th Cong., 1st Sess., 91 CoNG. REC. 330 (1945) reprinted at Appendix B infra.

48. 91 CONG. ReC. 464, 478-88 (1945).

49. See, e.g., 91 CONG. REC. 479-82, 485-87 (1945).

50. Id. 484. See also id. 479-82, 485-86 (remarks of Sens. O'Mahoney, Murdock and Taft).

51. Id. 486. Section 2(b), with the Ferguson amendment language italicized, then read as follows:

No act [of Congress], except the act of July 2, 1890, as amended, known as the Sherman Act, and/or the act of October 15, 1914, as amended, known as the Clayton Act, shall be construed to invalidate, impair, or supersede any law enacted by any State for the purpose of regulating the business of insurance, or which imposes a fee or tax upon such Id. business, unless such act specifically so provides.

52. Id. 488.

53. The Ferguson amendment was the principal point of disagreement between the two houses. The three other basic changes recommended by the House Judiciary Committee were either minor or were resolved by the House leadership. In particular, two representatives later 
section 3(b) adding "agreements" to boycott. ${ }^{54}$ On February 19, the Senate and House each rejected the other's amended bill without debate and appointed their conference committee members. ${ }^{55}$ The conference report consisted almost entirely of a compromise version of S. 340 . The major change was the compromise over the Ferguson amendment to section 2(b), which involved adding an entirely new proviso clause affirmatively stating that the Sherman, Clayton and FTC Acts "shall be applicable to the business of insurance to the extent that such business is not regulated by State law."56

Notwithstanding the fundamental changes in S. 340, the House on February 23 agreed to the new version of S. 340 without debate. ${ }^{57}$ The Senate, on the other hand, discussed the conference report at length on February 26-27, and adopted it on the 27th. ${ }^{58}$ President Roosevelt signed the conference report version of S. 340 into the law known as the McCarran-Ferguson Act on March 9, 1945.99

named as House conferees on the bill resolved to add "agreements" to boycott during the House debates rejecting that term. 91 CoNG. REC. 1088 (1945) (remarks of Reps. McCormack and Walters). See note 54 infra.

54. The other two basic changes were to the moratorium provision, section 4(a), and consisted of deleting its purpose clause and of extending the Sherman Act moratorium to January 1, 1948. See Appendix B infra for the original text of section 4(a).

The House debated the House Judiciary Committee's recommended changes on February 1314 and adopted them on February 14, 1945. 91 CoNG. REC. 1084-85 (1945).

55. 91 Cong. Rec. 1208 (1945).

56. Id. 1396. Other changes were that section 3 was deleted from the bill entirely, the FTC Act was included in the section 2(b) proviso clause, and the FTC and Robinson-Patman Acts were made subject to the same three-year moratorium period as the Sherman and Clayton Acts in old section 4(a), which became new section 3(a). In addition, the Senate's boycott provision (now section 3(b)) covering agreements was adopted, and the House's moratorium provision without the purpose clause and with the single date January 1, 1948 was also accepted. Id.

57. Id. 1396.

58. Id. 1442-44, 1477-89. This bill moved very quickly for two reasons. First, the state insurance commissioners had been extremely successful at rallying what had been bitterly divided insurance interests and legislators around the Commissioners' Bill. Second, the date when state premium taxes were paid, generally March 1 of each year, was rapidly approaching, and, thus, substantial state revenues were imminently threatened. These taxes were an important source of revenue for the states, amounting to $\$ 126$ million in 1944 alone. W. FreEDMAN, RICHARDS on THE LAW OF INSURANCE $178 \mathrm{n} .9$ (5th ed. 1952).

59. Note, $A$ Year of S.E.U.A., 23 CHI.-Kent L. Rev. 317, 325 (1945). The citation of the original Act is ch. 20, 59 Stat. 33. The current version of the Act appears at Appendix A infra.

The importance of the Roosevelt administration's influence through threat of a presidential veto on the content and language of this legislation has been largely ignored in previous legislative histories of the McCarran-Ferguson Act. Probably the most important statement of the Roosevelt administration's views was contained in a letter from President Roosevelt to Senator Radcliffe on January 2, 1945, reprinted in 91 CoNG. REC. 482 (1945). The letter stated that the administration was not sponsoring any legislation to establish a federal regulatory agency for insurance and did not want to interfere in the continued regulation and taxation of insurance by the states. Moreover, Roosevelt said that he saw no conflict in the complementary application of state regulatory 


\section{The Implications of Legislative History, Language and Purposes IN APPLyING THE MCCarRan ACt}

Because the McCarran Act was passed in reaction to the S.E.U.A. litigation, the conventional history emphasizes the influence of proposals seeking a total exemption from the antitrust laws for the insurance industry. However, these proposals were defeated, ${ }^{60}$ and Congress turned instead to the approach advocated by the NAIC, a group concerned with preserving state taxing and regulatory powers, not with preempting the federal antitrust laws. The NAIC's indisputable imprint on the McCarran Act and the fundamentally federalist principles that were adopted are richly supported in the legislative history, but largely have been ignored by the courts. ${ }^{61}$

This section of the Article documents that the primary purpose of the McCarran Act was federalist and not preemptive in nature. It concludes that questions of McCarran Act antitrust immunity should be approached in two stages and develops suggested contours of that analysis.

\section{A. The Fundamentally Federalist Purposes of the McCarran Act.}

The NAIC origins of the McCarran-Ferguson Act are unmistakable in the legislative history and the texts of the two bills. ${ }^{62}$ The NAIC's highest priority and greatest success was the preservation of state insurance commissioners' powers of regulation and taxation. ${ }^{63}$ Sections 1 and 2 of the Act were specifically and technically drafted to meet commerce clause threats to the constitutionality of state tax and regulatory schemes. ${ }^{64}$

and federal antitrust laws, since the latter applied to private restraints of trade and not to affirmative state regulation. See note 34 supra.

60. See text accompanying notes $46-47,55-59$ supra.

61. Several commentators have pointed out the NAIC origins of the McCarran-Ferguson Act but have not adequately explored its implications. See, e.g., Mertz, supra note 13, at 158; Rose 693-94.

62. A detailed comparison of the Commissioners' Bill and the McCarran Act appears in 1945 NAIC PRoc. 157-60. The NAIC obtained everything it wanted, with two significant exceptions. First, the NAIC was unable to procure total insurance immunity from the FTC and the Robinson-Patman Acts. Second, the NAIC's bill did not include the crucial "to the extent regulated by state law" proviso clause in section 2(b) of the McCarranAct.

63. It is clear that the NAIC was concerned specifically and exclusively with preserving state insurance department regulation and taxation, and not with every state law, rule or regulation possibly applicable to insurance.

64. The section-by-section analysis in the November 16, 1944 NAIC Memorandum of Explanation expressly shows that sections 1 and 2 were based upon a package of commerce clause issues. Section 1 was drafted to neutralize the commerce clause doctrine of silence, which posed a real threat to the very existence of state regulation and taxation of insurance. Section 2(b), which in the NAIC draft did not include the proviso, was addressed to the commerce clause cases strik- 
The legislative history reveals that Congress' purposes were the same as those of the NAIC. Congress adopted "almost verbatim" the language of sections 1 and 2(a) of the Compromise Commissioners' Bill. ${ }^{65}$ Three House and Senate Reports on S. 340 express the identical concern about preserving state insurance regulation and taxation from constitutional invalidity:

Inevitable uncertainties which followed the handing down of the decision in the Southeastern Underwriters Association case, with respect to the constitutionality of State laws, have raised questions in the minds of insurance executives, State insurance officials, and others as to the validity of State tax laws as well as State regulatory provisions; thus making desirable legislation by the Congress to stabilize the general situation.

.. . Your committee believes there is urgent need for an immediate expression of policy by the Congress with respect to the continued regulation of the business of insurance by the respective States. Already many insurance companies have refused, while others have threatened refusal to comply with State tax laws, as well as with other State regulations, on the ground that to do so, when such laws may subsequently be held unconstitutional in keeping with the precedent-smashing decision in the Southeastern Underwriters case, will subject insurance executives to both civil and criminal actions for misappropriation of company funds. ${ }^{66}$

The Supreme Court on several occasions has specifically stated that the McCarran Act was primarily designed to protect state regulation and taxation from commerce clause infirmities. The most important of these cases, decided one year after passage of the Act, directly tested the constitutional purposes the NAIC and Congress sought to achieve in drafting sections 1 and 2. In Prudential Insurance Co. v. Benjamin, ${ }^{67}$ Prudential challenged the validity of a South Carolina tax imposed on out-of-state insurers. Prudential's chief argument was that the tax discriminated against interstate commerce in violation of the commerce clause. In upholding the South Carolina taxing scheme, the Court had occasion to discuss the purposes of the McCarran Act:

Obviously Congress' purpose was broadly to give support to the existing and future state systems for regulating and taxing the business of insurance. This was done in two ways. One was by removing

ing down state licensing schemes and was "designed to eliminate or at least minimize conflict between State laws and existing or future acts of Congress." NAIC Memorandum of Explanation, Nov. 16, 1944, reprinted in 90 CONG. REC. A4406-07 (1944).

65. 1945 NAIC Proc. 157-58.

66. H.R. ReP. No. 68, 79th Cong., 1st Sess. 2 (1945) (emphasis added); accord, H.R. REP. No. 143, 79th Cong., 1st Sess. 3, reprinted in [1945] U.S. CoDE CoNG. SERV. 670, 671; S. REP. No. 20, 79th Cong., 1st Sess. 1-2 (1945).

67. 328 U.S. 408 (1946). 
obstructions which might be thought to flow from its own power, whether dormant or exercised, except as otherwise expressly provided in the Act itself or in future legislation. The other was by declaring expressly and affirmatively that continued state regulation and taxation of this business is in the public interest and that the business and all who engage in it "shall be subject to" the laws of the several states in these respects.

...

.. . [Congress] clearly put the full weight of its power behind existing and future state legislation to sustain it from any attack under the commerce clause to whatever extent this may be done with the force of that power behind it, subject only to the exceptions expressly provided for. ${ }^{68}$

The commerce clause basis of the purpose clause and section 2 of the McCarran Act served to harmonize federal and state authority over insurance in three additional ways. First, these provisions of the Act indicate that Congress did not intend to usurp state insurance commissioners and to "federalize the regulation" 69 of insurance by establishing a new federal regulatory agency. Second, as the NAIC made clear, the intent was not to return to the days of exclusive state supervision of insurance:

68. Id. at 429-30, 431 (footnote omitted and emphasis added). The Court's references to "removing obstructions" and to "declaring" correspond to the NAIC's attention to the commerce clause doctrine of silence and consent. See note 64 supra. Three later Supreme Court cases seem to express similar constititutional concerns. In Maryland Cas. Co. v. Cushing, 347 U.S. 409 (1954), Mr. Justice Frankfurter cited section 1 of the McCarran Act and then observed:

Suffice it to say that even the most cursory reading of the legislative history of this enactment makes it clear that its exclusive purpose was to counteract any adverse effect that this Court's decision in United States v. South Eastern Underwriters Association . . . might be found to have on state regulation of insurance.

Id. at 413 (citation omitted). Similar language appears in Wilburn Boat Co. v. Fireman's Fund Ins. Co., 348 U.S. 310 (1955):

The measure Congress passed shortly thereafter, known as the McCarran Act, was designed to assure that existing state power to regulate insurance would continue. Accordingly, the Act contains a broad declaration of congressional policy that the continued regulation of insurance by the States is in the public interest, and that silence on the part of Congress should not be construed to impose any barrier to continued regulation of insurance by the States.

Id. at 319 (footnote omitted).

Again, in 1960, the Court noted that the basic purpose of the McCarran Act was to reaffirm state power to regulate and tax insurance:

The McCarran-Ferguson Act was passed in 1945. Its basic purpose was to allay doubts, thought to have been raised by this Court's decision of the previous year in United States v. South Eastern Underwriters Association . . . as to the continuing power of the States to tax and regulate the business of insurance.

FTC v. Travelers Health Ass'n, 362 U.S. 293, 299 (1960) (footnote and citation omitted).

69. NAIC August 29, 1944 Report, reprinted in 90 CoNG. REC. A4403-04 (1945). This Report also explains at length how earlier efforts to federalize insurance regulation had been rejected by Congress. 
[T]he state insurance commissioners did not accept the status quo concept. The NAIC rejection of the industry sponsored . . . [total exemption] "business as usual" bills served notice that the insurance commissioners did not accept the restoration of the status quo position held by much of the insurance industry. ${ }^{70}$

The NAIC's views were shared by Congress, as the McCarran Act expressly provides for the applicability of federal and state laws in specified ways to the business of insurance and thus rejects a return to the status quo and exclusive state jurisdiction. Senator Ferguson's remarks on the issue are informative:

Mr. McKellar. As I understand the bill its purpose and effect will be to establish the law as it was supposed to be prior to the rendering of the recent opinion of the Supreme Court of the United States. Is that correct?

Mr. Ferguson. No. ${ }^{71}$

Third, section 2(b) was drafted to minimize conflict and to give the states the ultimate, as opposed to the exclusive, policy-making authority for most issues involving the business of insurance.

The broad and sweeping language in sections 1 and 2 can easily be misread to extend beyond the constitutional problems that the Act was precisely tailored to solve. If loosened from the moorings of their limited purpose, these sections can lead to the inference that Congress intended to exclude or unduly restrict federal power. The problem is that "[s]uch an inference clearly violates the laws of logic-there is no logical transference from the proposition that the state can regulate to the proposition that the nation cannot regulate."72 The Supreme Court has repeatedly stated that federal and state authority should be accommodated if at all possible and that preemption should apply only when concurrent federal and state authority are irreconcilable. ${ }^{73}$ Moreover,

70. NAIC 35 (footnote omitted). It is important to distinguish sharply between what the NAIC might have really wanted and what the NAIC decided was politically feasible. The fact that the NAIC strongly backed the effort to have the Supreme Court reconsider and reverse itself in S.E.U.A. suggests that NAIC may have preferred a return to the days of exclusive state jurisdiction. See, e.g., Insurance Field (Life ed.), June 23, 1944, at 3. Nonetheless, it is clear that the NAIC abandoned any hope of returning to the status quo, for the Commissioners' Bill and its supporting materials do not advocate exclusive state supervision and there is no evidence that they took such a position before Congress.

71. 91 Cong. Rec. 478 (1945).

72. Timberg, Insurance and Interstate Commerce, 50 YALE L.J. 959, 967 (1941) (emphasis in original). Although Timberg was obviously writing in a pre-McCarran Act context, the logic of his argument remains unchanged.

73. A recent statement of these basic principles of federal-state comity and federalism is found in Merrill Lynch, Pierce, Fenner \& Smith, Inc. v. Ware, 414 U.S. 117 (1973):

So here, we may not overlook the body of law relating to the sensitive interrelationship between statutes adopted by the separate, yet coordinate, federal and state sovereignties. Our analysis is also to be tempered by the conviction that the proper approach is to 
the Court has specifically held that basic principles of federalism are to be applied in construing the McCarran Act. In Prudential, its first McCarran Act decision, the Court articulated the judiciary's fundamental duty in a federalist system to seek to accommodate federal and state authority:

The versatility with which argument inverts state and national power, each in alternation to ward off the other's incidence, is not simply a product of protective self-interest. It is a recurring manifestation of the continuing necessity in our federal system for accommodating the two great basic powers it comprehends. ${ }^{74}$

The next section of this Article applies principles of federalism and the usual tools of statutory construction to the specific issue of when Congress intended state insurance regulation to preempt the federal antitrust laws under section 2(b). It is assumed that the threshold issues for the applicability of the McCarran Act, such as the presence of an insurance product, ${ }^{75}$ activities within the "business of insurance," relevant body of state insurance $1 \mathrm{aw}^{77}$ and the required state regulatory agency, ${ }^{78}$ are present.

\section{B. A Two-Stage Test Under Section 2(b) for Federal Antitrust Immunity.}

1. The First Stage of the Test: Do the Federal Antitrust Laws "Invalidate, Impair, or Supersede" State Insurance Regulation? The first clause of section 2(b) provides: "No Act of Congress shall be construed to invalidate, impair, or supersede any law enacted by any State for the purpose of regulating the business of insurance . . ." Al9 Although this clause tends to be ignored in cases involving the Sherman, Clayton or FTC Acts, ${ }^{80}$ the legislative history and language indicate that the first

reconcile "the operation of both statutory schemes with one another rather than holding one completely ousted."

Id. at 127 (quoting Silver v. New York Stock Exch., 373 U.S. 341, 357 (1963); accord, Perez v. Campbell, 402 U.S. 637 (1971); Florida Lime \& Avocado Growers, Inc. v. Paul, 373 U.S. 132 (1963); Bibb v. Navajo Freight Lines, Inc., 359 U.S. 520 (1959); Huron Cement Co. v. City of Detroit, 362 U.S. 440, 443-44 (1950).

74. 328 U.S. at 412 (footnote omitted and emphasis added.)

75. See note 174 infra.

76. See text accompanying notes 175-211 infra.

77. Not all state laws are relevant in determining McCarran Act immunity; the only pertinent state laws are those "enacted for the purpose of regulating the business of insurance." SEC $\mathrm{v}$. National Sec., Inc., 393 U.S. 453, 457 (1969). See, e.g., Weller, supra note 12, which concludes that state antitrust laws are not among the class of state laws that can trigger McCarran Act antitrust immunity.

78. See text accompanying notes 95-154 infra.

79. 15 U.S.C. $\$ 1012(b)(1976)$.

80. The apparent interpretation of section 2(b) has been that the second clause (the proviso clause) is the only one that applies to the Sherman, Clayton and FTC Acts, and that the first 
clause is equally applicable to those statutes.

It was this provision in S. 340 as originally proposed and as first passed by the House that governed the applicability of the Sherman and Clayton Acts and permitted the states to establish rating bureaus or otherwise to act inconsistently with the antitrust laws. It caused the major split between the House and the Senate over the extent to which state insurance law could preempt the federal antitrust laws. ${ }^{81}$ The House took the position that if there were a conflict, state law would prevail. ${ }^{82}$ The Senate, on the other hand, felt that in the case of a conflict the antitrust laws would prevail. ${ }^{83}$ Both houses clearly agreed, however, that where there was no conflict the Sherman and Clayton Acts would continue to be applicable. ${ }^{84}$ The proviso clause, which neither house included in its bill, was the product of the conference committee and was apparently the compromise between preemption by the states versus preemption by federal law in the event of a conflict. ${ }^{85}$ Since both houses agreed that federal antitrust laws give way only when they conflict with state law, there is no reason to suppose that the conference committee intended to alter this policy. Moreover, the ineluctable fact is that the proviso evolved from the stalemate between the two chambers over the "invalidate, impair, or supersede" standard as applied to the Sherman and Clayton Acts. It would be perverse indeed to construe the proviso clause as imposing a lesser standard than the Senate could have obtained from the House without taking the dispute to conference. It was certainly the understanding of the Senate, the only house to discuss the conference report, that the proviso clause did not significantly weaken the earlier bill. In fact, excerpts from the Senate debate indicate that, at least in the minds of two influential senators,

clause applies to all other federal laws not otherwise covered in the Act. See text accompanying note 88 infra.

81. See text accompanying notes $49-56$ supra.

82. The House version provided that the Sherman and Clayton Acts were subject to the "invalidate, impair, or supersede" language of section 2(b) under the original form of S. 340. See Appendix B infra. The FTC and Robinson-Patman Acts were to be completely inapplicable to insurance under section 3 of S. 340 .

83. The Senate version with the Ferguson amendment provided: "No Act of Congress, except the . . . Sherman Act . . . and . . . Clayton Act, shall be construed to invalidate, impair, or supersede...." See note 51 supra.

84. "Conflict" is used here as shorthand for section 2(b)'s "invalidate, impair, or supersede" standard. The House text of section 2(b) provided that the Sherman and Clayton Acts applied so long as they did not "invalidate, impair, or supersede" state insurance regulation. The Senate version, with the Ferguson amendment, provided that the Acts would apply regardless of state insurance regulation. Thus, under both versions of S. 340 as originally passed, the Sherman and Clayton Acts applied when there was no conflict with state insurance regulation.

85. H.R. REP. No. 213, 79th Cong., Ist Sess. (1945), reprinted in 91 CoNG. REC. 1357 (1945). 
section 2(b) was stronger, not weaker, with the proviso clause. ${ }^{86}$

The affirmative declaration in the proviso clause that the Sherman, Clayton and FTC Acts "shall be applicable" is consistent with this interpretation. The affirmative language makes explicit that Congress did not consider antitrust principles to be wholly alien to the insurance industry, a conclusion that is only implicit in the negative form of the first clause.

Additional support for the view that section 2(b) was stronger with the proviso is provided by the NAIC's adverse reaction to the clause soon after the McCarran Act was enacted. ${ }^{87}$ The NAIC had agreed that Sherman and Clayton Act immunity should be measured by an "invalidate, impair, or supersede" test. The proviso clause added something new and, as a compromise with the stricter Senate position, suggested a more stringent test.

It can be argued that Congress did not intend to use the proviso clause in its customary fashion, but instead meant it to operate as an exceptions clause. The proviso could be read as excepting the three laws from the first clause and subjecting them to the standards of the proviso clause alone. This interpretation of a proviso clause is unusual, but is not without precedent. ${ }^{88}$

As a technical matter of statutory construction, there are several indications that Congress intended the section 2(b) proviso to operate in its normal manner and not as an exceptions clause. First, Senator O'Mahoney, one of the Senate conferees, stated that both clauses of section 2(b) would apply to the Sherman, Clayton and FTC Acts. ${ }^{89}$

86. At one point in the final Senate debates of February 26-27, Senator McCarran, a member of the conference committee, responded to Senator Pepper's objections to the proviso clause by stating that it made section 2(b) "more airtight":

Mr. McCarran. Let me say to the Senator the language which he has just read to the Senate [the proviso clause] was put in by the conferees within the scope of their authority, and if it did anything it made more airtight the very provision the Senate had passed in the first instance and which the House had also passed.

91 CONG. REc. 1478 (1945).

Later in the same debate, Senator Murdock, a strong supporter of the Ferguson amendment in the first Senate debate, expressed the view that the conference committee version of S. 340 was better. Id. 1489.

87. In an address to his fellow state insurance commissioners, NAIC President Newell Johnson compared the McCarran Act to the NAIC proposal and spoke of the proviso clause as follows:

Generally speaking we had tried originally to cut a pattern for state regulation which we had reason to believe the Congress would approve. If such a pattern had been provided, we would not now face the vexing problem of trying to determine the meaning of the phrase "to the extent that such business is not regulated by State Law."

1945 NAIC Proc. 143 (emphasis added).

88. See 1A, 2A C. Sands, StatuTES AND STatutory Construction $\$ \$ 21.11,47.08,47.09$ (4th ed. 1972).

89. During an exchange with Senator O'Mahoney on February 26, Senator Pepper argued 
Second, Congress had abandoned the Ferguson amendment, which, as adopted by the Senate, provided: "No act of Congress, except . . . the Sherman Act, and/or . . . the Clayton Act, shall be construed to invalidate, impair, or supersede any law enacted by any State for the purpose of regulating the business of insurance . . . .90 If Congress had intended to exclude these three acts from the first clause, it could have simply retained the Ferguson amendment and added an exception for the FTC Act. Thus, the better view is that the proviso limits the reach of section 2(b)'s first clause and is not an exceptions clause. ${ }^{91}$

In view of this history, the proper first step in a McCarran exemption case is to inquire whether the federal antitrust laws "invalidate, impair, or supersede" state insurance law. When such a conflict exists, the first clause of the McCarran Act operates as a "reverse supremacy clause," requiring the federal law to give way when state and federal laws cannot be reconciled. As with the constitutional supremacy clause, ${ }^{92}$ the Supreme Court has made clear that the first clause of section 2(b) requires state preemption only when federal and state authority are irreconcilable. In $S E C$ v. National Securities, Inc. ${ }^{93}$ the Court held that the SEC's attempt to enjoin a state-approved merger between two insurance companies was not an "impairment" of state law. The Court indicated that the inconsistency must be absolute - the state must have "commanded something which the Federal Government seeks to prohibit." Thus, the "invalidate, impair, or supersede" standard of section 2(b) should be applied as a first stage or minimum standard before the McCarran Act's federal antitrust immunity is granted. This approach is in accordance with the Act's federalist purpose of first accommodating federal and state authority and avoids the granting of a

that S. 340 should identify the specific activites that would be exempted from the Sherman and Clayton Acts. Senator O'Mahoney replied:

I quite agree with the Senator, and I endeavored to the very best of my ability to induce the committees of Congress to write into the law specific exemptions from the antitrust law, but I was unable to prevail in the Committee on the Judiciary and I was unable to prevail on the floor of the Senate. But now we have this declaration that with respect to these particular acts, the Sherman Act, the Clayton Act, the Federal Trade Commission Act, no act of Congress shall be construed to invalidate the law of any State passed for the regulation or the taxing of the business of insurance, and then the proviso.

91 CoNG. REC. 1444 (1945) (emphasis added).

90. Id. 487 (emphasis added).

91. Even if the proviso were treated as an exceptions clause, the "invalidate, impair, or supersede" standard of the first clause should still be applied as a minimum test for federal antitrust immunity. Since the House had adopted that standard and the Senate demanded a stricter standard, the proviso compromise could not have been anything less than that to which the House had already agreed.

92. See note 73 supra.

93. 393 U.S. 453 (1969).

94. Id. at 463. 
more lenient exemption from the federal antitrust laws than Congress intended.

\section{The Second Stage of the Test: The Federal Antitrust Laws Shall} Apply to the Extent the Business of Insurance is Not Regulated by State Law. While there has been a dearth of judicial and law review commentary on the applicability of the "impair, invalidate, or supersede" standard to questions of McCarran Act immunity from the federal antitrust laws, the many issues raised in applying section 2(b)'s proviso clause have not shared the same fate. ${ }^{95}$ Most of the debate over the proviso clause has involved the issue of whether mere regulatory legislation is sufficient or whether state regulation actually must be "effective" to meet the proviso's "regulated by state law" test. ${ }^{96}$ This Article

95. One of the issues has even been resolved by the Supreme Court, so that it is now clear that one state's "regulation" of practices affecting residents of a second state cannot preempt the Sherman, Clayton or FTC Acts in the second state. FTC v. Travelers Health Ass'n, 362 U.S. 293 (1960). The case involved deceptive trade practices, but its reasoning narrowing the McCarran exemption should apply a fortiori to the Sherman Act, the Clayton Act and the unfair competition aspect of the FTC Act since exemptions from the antitrust laws are narrowly construed. See, e.g., Federal Maritime Comm'n v. Seatrain Lines, Inc., 411 U.S. 726, 733 (1973).

96. The Supreme Court arguably decided against an "effective" regulation test in FTC v. National Cas. Co., 357 U.S. 560 (1958), at least with respect to deceptive trade practices under section 5 of the FTC Act. The Court rejected the FTC's argument that there was no "regulation" because state insurance statutes prohibiting unfair and deceptive practices were "inchoate" and had not crystallized into "administrative elaboration" of standards of conduct nor been applied in individual cases. Id. at 564. The Court's rejection of this argument suggests that the "effectiveness" of the state insurance scheme was irrelevant. Because the Court did not specifically address the "effectiveness" issue and since the controlling facts in the opinion are ambiguous, several commentators have argued that the "effectiveness" question is still open. Professor Keeton has observed:

The rationale of the opinion suggests the possibility that the mere enactment of some form of prohibitory statute is not conclusive of the question whether the business is "reg. ulated by State law." It might be concluded, for example, that prohibitory legislation is alone enough to constitute preemptive regulation of the field of false advertising but that something more is required to preempt the more complex field of antitrust regulation. It may even be questioned whether state legislation will alone be enough to preclude application of the Federal Trade Commission Act in all circumstances.

Certainly it is open to the Supreme Court to conclude that, in determining whether the insurance business is to some extent "not regulated by State law," it may consider not only the statutes and the administrative structure established by statutory direction or authorization but also the practical effectiveness of the state regulatory scheme.

KEETon 541 (footnote omitted). See also Crawford v. American Title Ins. Co., 518 F.2d 217, 22223 (5th Cir. 1975) (Godbold, J., dissenting); Rose 709. Additionally, the National Casually Court was not faced with reconciling the McCarran Act and the antitrust laws; the decision is thus of even more uncertain meaning in the antitrust context.

Lower courts have generally held that mere regulatory legislation is sufficient, see, e.g., Ohio AFL-CIO v. Insurance Rating Bd., 451 F.2d 1178 (6th Cir. 1971), cert. denied, 409 U.S. 917 (1972), while commentators have generally favored an "effective" regulation test. See, e.g., Rose 705-16; Wiley, supra note 13, at 291-309; Note, State Regulation Under the McCarran Act, 47 Tulane L. Rev. 1069 (1951); Note, State Supervision Over Insurance Rate-Making Combinations Under the McCarran Act, 60 YALE L.J.160 (1951). But see Morris, Meaning of Term "Regulated" by State Law" in Public Law 15, 1949 ABA Proc., SECTION OF INs. L. 213, 221-22. This issue is 
will focus, however, on two issues under the proviso clause that have either been neglected or forgotten: the significance of the clause's "to the extent that" language and the relationship, if any, of the Parker doctrine to the application of the proviso clause. ${ }^{97}$ This two-pronged inquiry is prompted by two significant trends in the application of the McCarran Act's limited exemption from the federal antitrust laws. First, the courts are increasingly faced with new insurance arrangements that raise novel questions of proviso clause interpretation. No longer are the states merely regulating rating bureaus, which was the principal issue addressed by Congress in fashioning the McCarran Act. ${ }^{98}$ Some of the most novel and difficult of these questions arise in the context of insurance arrangements having a substantial impact on industries outside insurance, such as automobile repair shops, hospitals, doctors, pharmacists and dentists. Second, recent cases have held that the proviso clause is satisfied if a state has generally authorized or permitted certain standards of conduct. This vague language has the potential of glossing over the many serious issues raised by these new arrangements.

(a) The forgotten "to the extent that" language. The legislative history of the proviso clause indicates that Congress never intended state insurance department regulation of some insurance company activities to be enough to completely oust the federal antitrust laws for all activities. Otherwise a gap would exist where neither federal nor state law applied, and the public would be left wholly unprotected. The "to the extent that" language was intended to avoid any gap and to require specific state regulatory authority over the activity in question before McCarran Act immunity would exist. ${ }^{99}$

not unique to the McCarran Act, but is recurrent in antitrust litigation involving regulatory agencies. See, e.g. Gordon v. New York Stock Exch., 422 U.S. 659, 692 (1975) ("only if the SEC is actively and aggressively exercising its powers of review and approval can we be sure that fixed commission rates are being monitored in the manner which Congress intended") (Douglas, J., concurring).

97. The analysis is restricted to the Sherman Act, the Clayton Act and the unfair methods of competition branch of the FTC Act. Arguably, the Supreme Court has definitively decided the standard for the unfair or deceptive trade practices branch of the FTC Act in FTC v. National Cas. Co., 357 U.S. 560 (1958). Also, congressional intentions are more clearly articulated regarding the antitrust laws, and the Sherman and Clayton Acts in particular, than they are regarding deceptive trade practices.

98. "Congress was mainly concerned with the relationship between insurance ratemaking and the antitrust laws, and with the power of the States to tax insurance companies." SEC v. National Sec., Inc., 393 U.S. 453, $458-59$ (1969).

99. W. FREEDMAN, supra note 58 , at $189-90$. 
Senator Murdock, one of the champions of the antitrust laws throughout the legislative development of the McCarran Act, expressed this understanding of section 2(b):

I agree thoroughly with the Senator from Maine [Senator White] that insofar as the States step into the picture affirmatively and act by regulation, they may do so. As the Senator from Wyoming [Senator O'Mahoney] has said, we convey no authority, we simply recognize their right to regulate. Insofar as they fail to cover the same ground covered by the Sherman Act and the Clayton Act, those acts become effective again. ${ }^{100}$

Although Congress was sharply divided over certain issues, there appeared to be a clear consensus that the McCarran Act would not tolerate the "private governments" established by the insurance companies involved in the S.E.U.A. litigation. Senator O'Mahoney eloquently articulated these views during one of his arguments in favor of the conference committee version of S. 340:

Mr. President, there are three forms of regulation. There is State regulation. . . . There is Federal regulation as a legal possibility, but no one is urging it now.

The third, and this has been harmful to the public interest, is regulation by private combination and groups; a type of regulation which has been enforced by private combinations and groups through private rules and regulations under which persons engaged in the insurance industry could be tried and convicted for the violation of private law. That type of regulation would be absolutely outlawed should the conference report be adopted. ${ }^{101}$

Several post-McCarran enactment materials provide further confirmation of this result. In an important 1948 article, Senator McCarran unambiguously made this point:

State regulation in such a field, to constitute an effective assertion of jurisdiction, probably would have to meet certain minimum standards. The State law should be explicit with respect to the practice which it is sought to regulate. Probably also the State law should be prohibitory rather than permissive. That is, it should prohibit the particular practice except in accordance with specified procedure and subject to State approval, rather than simply in terms permitting the practice in question. ${ }^{102}$

100. 91 CoNG. REC. 1444 (1945) (remarks of Sen. Murdock) (emphasis added). Senator Ferguson, on the day the McCarran Act was passed, made this exact point:

But with respect to anything else than boycott, coercion and intimidation, if the States were specifically to legislate upon a particular point, and that legislation were contrary to the Sherman Act, the Clayton Act, or the Federal Trade Commission Act, then the State law would be binding.

Id. 1481 (remarks of Sen. Ferguson) (emphasis added).

101. Id. 1483 (remarks of Sen. O'Mahoney) (emphasis added).

102. McCarran, Federal Control of Insurance: Moratorium Under Public Law 15 Expired July 
Interpreting the McCarran Act to create antitrust immunity in the absence of specific regulatory authority over the anticompetitive conduct would be wholly unprecedented. In other regulated industries such as railroads, airlines, banks and utilities, courts have consistently held that there can be no antitrust immunity when a regulatory agency is without specific authority over the anticompetitive conduct. ${ }^{103}$ As with the McCarran Act, consensus quickly breaks down as to what in addition to specific regulatory authority must exist before antitrust immunity may be found. In no industry, however, is an exemption granted where there is less than specific authority. There is no reason to believe that Congress intended, or that the Supreme Court will permit, insurance to be the first. Indeed, the affirmative language in the proviso clause that the antitrust laws "shall be applicable to the business of insurance" could be read to codify the well-established principle that the antitrust laws apply to activities beyond the authority of a regulatory agency.

Most courts that have applied the proviso clause have found specific regulatory authority before granting antitrust immunity under the McCarran Act. ${ }^{104}$ The first case granting a McCarran Act antitrust ex-

1, 34 A.B.A.J. 539, 542 (1948) (emphasis added). Senator McCarran also listed several other factors to be considered under the proviso clause, none of which is pertinent to the precise issue here but which are worth noting:

Machinery should be provided for regulating the practice, and the law should designate an authority, in either some official or some agency of the State, to exercise the State regulatory power. It should lay down general standards to govern the discretion to be exercised by such authority. Probably it should also include provisions for public notice, and an opportunity for hearing, in advance of the exercise of such discretionary authority; and there should be some provision for appeal from the decisions made by such authority. Id.

103. See, e.g., United States v. National Ass'n of Sec. Dealers, 422 U.S. 694 (1975); Gordon v. New York Stock Exch., Inc., 422 U.S. 659 (1975); FMC v. Seatrain Lines, Inc., 411 U.S. 726 (1973); Otter Tail Power Co. v. United States, 410 U.S. 366 (1973); Hughes Tool Co. v. Trans World Airlines, Inc., 409 U.S. 363 (1973); United States v. Philadelphia Nat'l Bank, 374 U.S. 321 (1963); Pan Am World Airways v. United States, 371 U.S. 296 (1963); Georgia v. Pennsylvania R.R., 324 U.S. 439 (1945). See also California v. FPC, 369 U.S. 482 (1962). There have been instances where a regulatory agency has disputed that it had the authority, but the Supreme Court, the final arbiter of such disputes, has always ruled the authority was there. See, e.g., Hughes Tool Co. v. Trans World Airlines, Inc., 409 U.S. 363, 409 (1973) (Burger, C.J., dissenting).

104. See, e.g., Meicler v. Aetna Cas. \& Surety Co., 506 F.2d 732 (5th Cir. 1975); Commande Leasing Co. v. Transamerica Title Ins. Co., 477 F.2d 77 (10th Cir. 1973); Frankford Hosp. v. Blue Cross, 417 F. Supp. 1104 (E.D. Pa. 1976), affd, 554 F.2d 1253 (3d Cir.), cert denied, 98 S. Ct. 186 (1977); Steingart v. Equitable Life Assurance Soc'y, 366 F. Supp. 790 (S.D.N.Y. 1973); Fleming v. Travelers Indem. Co., 324 F. Supp. 1404 (D. Mass. 1971); Allstate Ins. Co. v. Lanier, 242 F. Supp. 73 (E.D.N.C. 1965), aff'd, 361 F.2d 870 (4th Cir.), cert. denied, 385 U.S. 930 (1966); In re Aviation Ins. Indus., 183 F. Supp. 374 (S.D.N.Y. 1960); Miley v. John Hancock Mut. Life Ins. Co., 148 F. Supp. 299 (D. Mass.), affd per curiam, 242 F.2d 758 (Ist Cir.), cert. denied, 355 U.S. 828 (1957). See also Traveler's Ins. Co. v. Blue Cross, 481 F.2d 80 (3d Cir.), cert. denied, 414 U.S. 1093 (1973) (involving alleged antitrust violations relating to Blue Cross hospital insurance rates resulting 
emption, North Little Rock Transportation Co. v. Casualty Reciprocal Exchange, ${ }^{105}$ is representative. The plaintiff, a taxicab company unhappy over higher insurance premiums resulting from the adoption of experience rating, alleged that the defendant insurance companies had fixed prices through a rating bureau licensed under Arkansas law. The district court and the court of appeals held that the Sherman Act was inapplicable under section 2(b) because Arkansas' casualty rating law specifically "regulated" insurance rates and the rating bureau.

The few cases that have begun to deviate from this strong line of authority have relied on dicta from California League of Independent Insurance Producers v. Aetna Casualty Surety Co. ${ }^{106}$ The court in that case stated that "if a State has generally authorized or permitted certain standards of conduct, it is regulating the business of insurance under the McCarran Act."107 In California League the plaintiffs were insurance agents who accused various insurance companies of fixing commission rates. The court found that the California rating law expressly authorized insurers to cooperate in rate making and in setting commission rates, but prohibited insurance companies from agreeing on rates. ${ }^{108}$ In denying the defendants a McCarran Act antitrust exemption, the court held that although the proviso clause of section 2(b) was satisfied, the price-fixing conspiracy was effectuated by means of boycott, coercion or intimidation and thus was illegal by virtue of section 3(b). ${ }^{109}$ The court reached the right result but for the wrong reasons. The court should have held that neither section 2(b) nor section 3(b) was satisfied. Since California did not regulate insurance rate making and actually prohibited rate agreements, the court erred in concluding that section 2(b)'s "to the extent . . . regulated by state law" test had been met. The better view would have been to have read section 2(b)

from favorable contracts with area hospitals giving Blue Cross a 14-15\% discount in the price it paid for hospital services; the Third Circuit based a McCarran-Ferguson exemption upon the fact that both Blue Cross rates and contracts with provider hospitals were specifically and aggressively regulated by the Pennsylvania Department of Insurance); Schwartz v. Commonwealth Land Title Ins. Co., 374 F. Supp. 564 (E.D. Pa. 1974) (plaintiff alleged price fixing in title insurance rate making and the court held it was immunized because of the specific authority of the Pennsylvania Departmeat of Insurance to regulate title insurance rates); Nankin Hosp. v. Michigan Hosp. Serv., 361 F. Supp. 1199 (E.D. Mich. 1973) (Michigan Department of Insurance specifically regulated Blue Cross rates and standards for participation by hospitals, which were the basis of plaintiffs antitrust complaint).

105. 85 F. Supp. 961 (E.D. Ark. 1949), affd, 181 F.2d 174 (8th Cir.), cert. denied, 340 U.S. 823 (1950).

106. 175 F. Supp. 857 (N.D. Cal. 1959).

107. Id. at 860 .

108. Id.

109. Id. at 861 . 
and section 3(b) as complementary rather than contradictory provisions.

The sole authority cited by the court in California League for its "generally authorized or permitted" language was the Supreme Court's decision in FTC v. National Casualty Co. ${ }^{110}$ The National Casualty Court rejected the FTC's argument that no McCarran Act exemption from the deceptive practices provision of the FTC Act should lie when state regulation is "inchoate"; the Alabama Insurance Commissioner in that case had the regulatory authority to remedy the deceptive advertising practices challenged by the FTC, but apparently had never exercised that authority. The California League court erred in failing to note the National Casualty Court's distinction between the presence of regulatory authority and the absence of regulatory action. The Supreme Court's tolerance of the Alabama Insurance Commissioner's policy of not enforcing Alabama insurance law could be interpreted to mean he "generally authorized or permitted" certain practices, but no more. The National Casualty decision certainly does not hold that a lack of regulatory authority by the Alabama insurance commissioner would have led to the same result of FTC preemption under the McCarran Act.

The Sixth Circuit's decision in Ohio AFL-CIO v. Insurance Rating Board ${ }^{111}$ quoted the California League dicta and in turn has been frequently cited for the same proposition. ${ }^{112}$ In that case, the plaintiffs asserted a conspiracy by the Ohio superintendent of insurance and 129 insurance companies to fix automobile insurance rates through the statutorily created Insurance Rating Board. The court of appeals noted that Ohio had a "comprehensive scheme for regulating practically all aspects of the business of insurance," 113 but that was not sufficient for the holding of the case. The court went on to state that the "crucial" factor in exempting the activity was the specific authority of the Ohio Department of Insurance to regulate the rate-making activity challenged by the plaintiffs as price fixing. ${ }^{114}$ However, the court did reject the plaintiffs' argument that only legislation coupled with "effective" enforcement could trigger McCarran Act immunity.

Although Ohio AFL-CIO certainly does not hold that general regulatory authority can provide McCarran Act antitrust immunity, a few

110. 357 U.S. 560 (1958) (per curiam).

111. 451 F.2d 1178 (6th Cir. 1971), cert. denied, 409 U.S. 917 (1972).

112. See, e.g., Mathis v. Automobile Club Inter-Ins. Exch., 410 F. Supp. 1037, 1041 (W.D. Mo. 1976); Steingart v. Equitable Life Assurance Soc'y, 366 F. Supp. 790, 794 (S.D.N.Y. 1973).

113. $451 \mathrm{~F} .2 \mathrm{~d}$ at 1182 .

114. $I d$. 
cases nevertheless have so held. The most explicit is McIlhenny $v$. American Title Insurance Co., ${ }^{115}$ which involved an alleged conspiracy by title insurance companies to tie the purchase of mechanic's lien insurance to the purchase of title insurance. The court dismissed the complaint on McCarran Act grounds, citing Pennsylvania's "pervasive, general control of the insurance industry" 116 and the California League line of cases. The court expressly ruled that "the fact that no statute or regulation specifically deals with the practice here in question is irrelevant." 117 This ruling, which was probably inevitable once the "generally authorized or permitted" language gained currency, plainly contradicts and is unsupported by the McCarran Act's legislative history, language and purposes.

Two other cases illustrate the fallacy of failing to analyze thoroughly whether the state insurance commissioner possesses the requisite authority to regulate the practices at issue. Lawyers Title Co. v. St. Paul Title Insurance Corp. ${ }^{118}$ involved a claim that St. Paul Title had engaged in predatory pricing of title insurance in the St. Louis area in violation of section 2 of the Sherman Act. Title insurance rates in Missouri were not set through a rating bureau, and so the court did not rely on that type of statute. Instead, the court cited various general provisions regarding the powers of the state Superintendent of Insurance to conduct periodic examinations of accounts and to hold public hearings and then singled out as the governing provision a Missouri statute providing that title insurance rates "shall not be unfairly discriminatory between risks involving essentially the same hazards." "119 After citing the California League dicta, the court stated that the laws of Missouri "expressly regulate price discrimination." 120

It is difficult to see why the court considered unfair discrimination statutes under insurance law to be dispositive of a predatory pricing claim under antitrust law. Professor Keeton points out that discriminatory rate statutes are intended to avoid "the result of unreasonably high rates to some policyholders and unreasonably low rates to others"; 121 that is, such statutes insure that policyholder premiums are commensu-

115. 418 F. Supp. 364 (E.D. Pa. 1976).

116. Id. at 369.

117. Id.. at 371. The court also relied upon Pennsylvania's unfair practices act for the proposition that Pennsylvania's insurance commissioner had statutory authority to address the challenged practice. Id. at 370 n.5. For a critique of using state antitrust laws to trigger federal antitrust immunity, see Weller, supra note 12.

118. 526 F.2d 795 (8th Cir. 1975).

119. Id. at 797.

120. Id. at 798 .

121. KeEton 557 (footnote omitted). See generally id. 559, 561, 565-67. 
rate with their risk. The consequence is that certain risk classifications are removed from the competitive arena. However, this regulatory objective has no bearing on predatory pricing aimed at driving other insurers out of business. It is still perfectly possible for the insurer to set its prices across the board at predatorily low levels without running afoul of this state regulation. Similarly, not all price differentials in premium rates can be attributed to unfair risk classifications. Predatory pricing within "fair" classifications is simply not addressed by the statute cited by the Lawyers Title court. Under such circumstances, antitrust policy should supplement state insurance regulation. The plaintiff made an argument to that effect, urging that Missouri law would not be "invalidated, impaired, or superseded" by the application of the Sherman Act. ${ }^{122}$ The court summarily rejected this argument, citing the California League dicta.

A subsequent district court case similarly applied state insurance law to a problem it was not intended to address. Pierucci v. Continental Casualty Co. ${ }^{123}$ was a class action on behalf of architects, engineers and others who purchased malpractice insurance. The complaint alleged that the defendant insurance companies had violated sections 1 and 2 of the Sherman Act by adopting a policy term that restricted coverage to malpractice claims filed during the policy period.

Relying on the California League-Ohio AFL-CIO dicta, the court focused upon a provision requiring insurance department approval of insurance policies and contracts: "If there are complaints about improvident approval of this form as to professional liability insurance such complaints should be taken to the Pennsylvania Insurance Commissioner and not to this court." 124 The court's reliance upon this type of statute was misplaced. The purpose of state insurance laws providing for administrative approval of policy forms is to provide policyholders with the benefits of a standardized insurance contract. ${ }^{125}$ Moreover, as Professor Keeton has pointed out, the extent of an insurance commissioner's authority is apt to be quite limited. ${ }^{126}$ Considering the plaintiff's allegation that a conspiracy to restrain trade was involved, it is difficult to see how the Pennsylvania Insurance Commissioner's authority to approve or disapprove forms could be construed to be specifically tailored to regulate restraints of trade resulting from concerted form making. This type of insurance regulation is markedly different

122. 526 F.2d at 797.

123. 418 F. Supp. 704 (W.D. Pa. 1976).

124. Id. at 709 .

125. KeETON 68-73.

126. Id. 71-72. 
from the concerted rate-making statutes that the McCarran Act was so clearly intended to permit. First, there is no provision for either any analogue to the licensed rating bureaus or for any other type of supervised concerted action. Second, the rating bureau statutes were developed after long and careful study for the express purposes of substituting rate regulation for competition and at the same time satisfying the McCarran Act's requirements. ${ }^{127}$ State purposes relating to these form approval laws are much less obvious and require far more probing analysis before the federal antitrust laws should be preempted. It is far from clear that the Pennsylvania insurance commissioner in Pierucci had the requisite specific authority to address a conspiracy to restrain trade.

In conclusion, the Supreme Court's first McCarran Act decision ${ }^{128}$ directly supports the need for a discriminating analysis of state regulatory authority. The Prudential Court sagely warned that insurers would be sure to try to play federal power off against state power and vice versa, "each in alteration to ward off the other's incidence." 129 As the Court predicted, insurers are apt to argue in state court that the state insurance commissioner is powerless to regulate them. The Ohio Supreme Court's ruling against the state insurance commissioner in Blue Cross v. Jump $p^{130}$ illustrates the incisiveness of the Supreme Court's caveat. On the other hand, when insurers are in federal court claiming McCarran Act immunity, they are apt to argue that the state insurance department is all powerful. Therefore, only a discerning legal analysis of the extent and purpose of the specific state regulatory authority at issue can insure the proper application of the McCarran Act to the federal antitrust laws. ${ }^{131}$ Otherwise, "private governments" can reign free from either federal antitrust or state regulatory authority, in direct contravention of congressional intent.

127. See generally NAIC 25-35 (1974).

128. Prudential Insurance Co. v. Benjamin, 328 U.S. 408 (1946).

129. Id. at 412 (footnote omitted). See 1959 NAIC Proc. 136-38.

130. 44 Ohio St. $2 d 78,337$ N.E.2d 783 (1975). In that case, a Blue Cross plan had filed an application for an average rate increase of $16 \%$. After a public hearing, the Superintendent denied the request on the grounds that Blue Cross had not met its duty under the "lawful, fair, and reasonable" standard then imposed by OHIO REv. CODE ANN. § 1739.051 (Anderson Supp. 1977). The Ohio Supreme Court reversed the Superintendent and allowed the rate increase, holding that the terms "lawful, fair, and reasonable" granted the Superintendent no authority to deny the rate increase merely because the Blue Cross plan did nothing to try to control rising hospital costs. The Ohio experience is not unique. See, eg., Patterson, The Future of State Supervisional Insurance, 23 TEX. L. REV. 18, 33-34 (1944).

131. This conclusion is fully consistent with and supported by the first clause of section 2(b). In the absence of specific regulatory authority, there is nothing that the federal antitrust laws could "invalidate, impair, or supersede." 
(b) The proviso and the Parker doctrine. The Parker or state action doctrine exempts state government and private parties from the federal antitrust laws in certain circumstances because of state regulation. Thus, Parker and the McCarran Act antitrust exemptions are analogous since both are premised on state regulation and both deal with delicate problems of federalism. ${ }^{132}$

What relationship, if any, exists between the Parker doctrine and the McCarran Act? The NAIC staff that prepared the two-volume 1974 study Monitoring Competition noted that "[s]ection 2(b) is essentially an enunciation of the Parker v. Brown decision." ${ }^{133}$ Certainly, the language of the proviso clause- "to the extent that such business is not regulated by state law"-is compatible with this interpretation. If the NAIC staff is correct, its conclusion has important implications for the application of the McCarran Act.

Parker was decided by the Supreme Court while Congress was considering the Walter-Hancock bills. On October 27, 1943, United States Attorney General Francis Biddle testified before Congress and cited the Parker decision along with other cases in arguing against the total-exemption bills. ${ }^{134}$ Both the House and Senate Reports on the Walter-Hancock bills rejected the Roosevelt administration's arguments, reasoning that "Parker $v$. Brown dealt with a State commission authorized by State statute to enforce a program in conformity with, if not supplementary to, a Federal statute. Obviously, all State regulation concerning insurance does not and would not fall in such a category." 135

After the Walter-Hancock bills were rejected by the Senate, Congress took up the NAIC's bill, S. 340. During congressional consideration of $\mathrm{S}$. 340, the proviso clause emerged as a compromise between the House and Senate texts of section 2(b). ${ }^{136}$ The Parker doctrine could well have been the compromise that the proviso clause codified, since it lies between the House and Senate positions that went to conference. Moreover, Senator O'Mahoney, one of the conferees on the bill, stated during the last day of Senate debates that the proviso clause embodied the Parker doctrine. ${ }^{137}$ His remarks arose in response to Senator Pepper's continuing concern over the proviso clause and his desire

132. See Blumstein \& Calvani, State Action As a Shield and a Sword in a Medical Services Antitust Context: Parker v. Brown in Constitutional Perspective, 1978 DUKe L.J. 389.

133. NAIC 27 n.58.

134. Joint Hearings, supra note 21, pt. 1, 49, 52-53.

135. H.R. Rep. No. 873, 78th Cong., 1st Sess. 7 (1943); S. REP. No. 1112, 78th Cong., 2d Sess. 5 (1944).

136. See text accompanying notes 81-85 supra.

137. 91 CoNG. REC. 1480 (1945) (remarks of Sen. O'Mahoney). 
that section 2(b) prohibit the states from regulating in a manner inconsistent with the Sherman and Clayton Acts. Senator O'Mahoney answered him as follows:

I take it that the Senator is apprehensive lest a statute passed by a State attempting to give validity to a private agreement to regulate would be recognized under [the proviso clause]. I think it would not, because. . . [in] Parker against Brown, I find this language from the Supreme Court:

"True, a State does not give immunity to those who violate the Sherman Act by authorizing them to violate it, or by declaring that their action is lawful."

Therefore I have no doubt in my own mind that no State, under the terms of the conference report, could give authority to violate the Sherman antitrust law. But we have this field in which definitions may be a little bit difficult and vague..$^{138}$

The repeated references during the Senate debates to the requirement that the states "affirmatively,"139 "specifically"140 and "adequately" ${ }^{141}$ regulate before the federal antitrust laws are displaced are fully consistent with a codified Parker doctrine interpretation. Most commentators have seen in this language an "effectiveness" mandate, yet the language is perfectly compatible with the Parker line of cases that have denied state action immunity for "what is essentially a private anticompetitive activity" 142 or for "individual action masquerading as state action." 143

This interpretation gains further support from the position taken by the Roosevelt administration at the time. President Roosevelt's famous January 2, 1945 letter to Senator Radcliffe contained the same language:

[T] here is no conflict between the application of the antitrust laws and effective State regulation of insurance companies, and there is no valid reason for giving any special exemption from the antitrust laws to the business of insurance. The antitrust laws prohibit private rate fixing arrangements between insurance companies and acts of boycott, coercion, or intimidation. The antitrust laws do not conflict with affirmative regulation of insurance by the States such as agreed insurance rates if they are affirmatively approved by State officials. ${ }^{144}$

138. Id. (citation omitted).

139. See, e.g., id. 1444 (remarks of Sen. Murdock).

140. See, e.g., id. 1443 (remarks of Sen. Ferguson).

141. See, e.g., id. 1444 (exchange between Sens. Barkley and McCarran).

142. Goldfarb v. Virginia State Bar, 421 U.S. 773, 792 (1975).

143. Asheville Tobacco Bd. of Trade, Inc. v. FTC, 263 F.2d 502, 509 (4th Cir. 1959); cf. Schwegmann Bros. v. Calvert Distillers Corp., 341 U.S. 384 (1951); Waynwright v. National Dairy Prod. Corp., 304 F. Supp. 567 (N.D. Ga. 1969) (federal antitrust laws apply only within the precise area left unregulated by a state statutory scheme).

144. 13 Public Papers and Addresses of Franklin D. Roosevelt: 1944-45, at 587 (Ro- 
The Roosevelt administration had long argued that the Parker doctrine struck the proper balance between preserving state regulation and the applicability of the antitrust laws. It is therefore not improbable that the President was using terms like "effective" and "affirmative" in his letter as a statement of what the Parker doctrine required before antitrust immunity could attach.

Nor was the Parker doctrine ignored by the NAIC when it prepared the Commissioners' Bill upon which the McCarran Act was based. The NAIC cited the Parker case for its bearing on the constitutional issues addressed in the purpose or policy section of its bill. ${ }^{145}$ In addition, the NAIC Memorandum of Explanation specifically relied upon Parker as a basis for exempting a list of activites from the Sherman Act:

This subsection, which would take effect July 1, 1948, is intended, among other things, to remove any doubt as to the validity of State regulation of insurance rates, and is based in a general way, upon the decision of the United States Supreme Court in the case of Parker v. Brown . . . . ${ }^{146}$

To date, only one court has adopted the NAIC view that the proviso clause essentially codifies the Parker doctrine. ${ }^{147}$ Even if this position is rejected, however, the Parker doctrine should serve as a helpful analogy in applying the McCarran Act antitrust exemption. Since the Supreme Court has not authoritatively decided the scope of that exemption, it would seem improvident to assume that the Court's recent pronouncements in Goldfarb and Cantor narrowing the closely related Parker doctrine have no implications whatsoever for the McCarran Act.

senman ed. 1950), reprinted in 91 CoNG. REC. 482 (1945) (emphasis added). The President voiced similar statements when he signed the McCarran Act into law two months later:

It is clear from the legislative history and the language of this Act, that the Congress intended no grant of immunity for monopoly or for boycott, coercion or intimidation. Congress did not intend to permit private rate-fixing, which the anti-trust act forbids, but was willing to permit actual regulation of rates by affirmative action of the states.

13 Public Papers and ADdresses of Frankin D. Roosevelt, supra, at 587.

145. NAIC Memorandum of Explanation, reprinted in 90 CoNG. REC. A4406 (1944). See text accompanying note 133 supra.

146. Id. A4407.

147. Allstate Ins. Co. v. Lanier, 242 F. Supp. 73 (E.D.N.C. 1965), cert. denied, 385 U.S. 930 (1966). The court stated:

What is of the utmost significance is that this decision of Parker v. Brown was considered at the time the McCarran Act was being considered and was specifically referred to on numerous occasions. Section 2(b) was written into the Act as an enunciation of the Parker $v$. Brown decision.

242 F. Supp. at 87 . In the context of the court's analysis, it is manifest that the court was specifically referring to the proviso clause. 
For example, the Court's Parker cases provide a valuable perspective on the Lawyer's Title and Pierucci decisions. In Goldfarb, the Court held: "The threshold inquiry in determining if an anticompetitive activity is state action of the type the Sherman Act was not meant to proscribe is whether the activity is required by the State acting as sovereign." 148 This Parker insight is directly applicable to the Pierucci case, where there was no indication whatsoever that the state had mandated or initiated a change from the "occurrence" to "claims made" coverage for malpractice insurance. Two more recent Parker decisions by the Supreme Court elaborate further on the threshold requirement. In Cantor and Bates v. State Bar of Arizona, ${ }^{149}$ the Court undertook an inquiry into whether "the State's policy is neutral" 150 regarding an anticompetitive practice or constitutes "an independent regulatory interest." 151 The Bates Court held that the Arizona Supreme Court's ethical prohibition against attorney advertising clearly expressed an independent state regulatory interest and was entitled to a Parker exemption. On the other hand, the Cantor Court found that a Michigan regulatory agency's approval of an electric utility company's tariff filing that included a free light bulb program did not express any independent state regulatory interest. ${ }^{152}$

In Lawyer's Title and Pierucci, the state insurance statutes cited by the courts did not reflect an independent regulatory interest on the issues of predatory pricing or conspiracies in restraint of trade perpetrated through collusive policy terms. State policy on these issues appeared at best to be neutral. Most McCarran-exemption cases have involved rating bureaus, where states have clearly chosen public utilitytype regulation over competitive price formation. In such cases, little analysis is usually required or found. Outside the rating bureau context, however, a far more discriminating legal analysis is necessary. State insurance statutes relating to unfair discrimination and administrative approval of forms, for example, carry no similar clear-cut policy choice by the states to preempt competition for regulation. Indeed, they may very well represent a deliberate choice by a state to establish miminum levels above which state policy fully intends competition to operate.

148. 421 U.S. at 790 (emphasis added).

149. 433 U.S. 350 (1977).

150. Cantor, 428 U.S. at 585 (five members of the Court-the Chief Justice and Justices Stevens, Brennan, White and Marshall-joined on this issue).

151. Bates, 433 U.S. at 361.

152. 428 U.S. at 585. 
The rating bureau decisions under the McCarran Act provide little help in applying section 2(b) to other types of state insurance laws. The overriding policy guiding that analysis should be the familiar federalism approach of seeking to accommodate federal and state authority if at all possible, so as to preempt the federal antitrust laws only when they are irreconcilable with state insurance regulation. ${ }^{153}$ Under the first stage of the test in particular, there should be no exemption if the federal antitrust laws do not "invalidate, impair, or supersede" state insurance regulation. ${ }^{154}$ Under the second stage, the "to the extent" language in the proviso clause requires that the state insurance department have specific regulatory authority to address the anticompetitive conduct at issue. Moreover, the Supreme Court's recent refinements of the Parker doctrine provide timely and cogent principles to aid in the analysis of new questions of McCarran Act antitrust immunity.

\section{The Boycott Limitation on Sherman Act Immunity Under Section $3(b)$.}

Section 3(b) of the McCarran Act is the second provision in which Congress expressed its intentions regarding the Sherman Act: "Nothing contained in this chapter shall render the said Sherman Act inapplicable to any agreement to boycott, coerce, or intimidate, or act of boycott, coercion, or intimidation." 155

Two of the central questions under the boycott provision are the range of boycotts covered and the interrelationship of sections $3(\mathrm{~b})$ and 2(b). ${ }^{156}$ The first question was resolved by the Supreme Court in St.

153. A similar policy governs the application of the twenty-first amendment's grant of authority to the states to regulate liquor sales. See United States v. Frankfort Distilleries, Inc., 324 U.S. 293 (1945).

154. See text accompanying notes 79-94 supra. The district court in Hamilton Life Ins. Co. v. Republic Nat'I Life Ins. Co., 291 F. Supp. 225 (S.D.N.Y. 1968), affd, 408 F.2d 606 (2d Cir. 1969), interpreted this language as follows: "There is no discernible evidence of a legislative intention that, in the absence of conflicting state regulatory legislation, federal statutes (such as the Federal Arbitration Act) would be inapplicable to the business of insurance." 291 F. Supp. at 230.

155. I5 U.S.C. $\& 1013(b)$ (1976).

156. Unfortunately, the NAIC's explanation for this provision in the Commissioners' Bill, section 4 (c), is uncharacteristically incomplete:

Subsection (c): This subsection, which has had previous reference, is to take effect immediately, and perhaps needs no detailed comment. It does not preclude the application of the Sherman Act to acts of boycott, coercion, and intimidation. In this regard it is to be noted that this subsection qualifies the suspension of the Sherman Act included in subsection (a).

90 CONG. REC. A4407 (1944). Boycotting, coercion and intimidation, of course, were among the practices with which the defendants in the S.E.U.A. indictments were charged. 322 U.S. at 535.

This Article does not analyze section 3(b) at length since this has been done elsewhere. See, e.g., Barry v. St. Paul Fire \& Marine Ins. Co., 555 F.2d 3 (1st Cir. 1977), affd, 98 S. Ct. 2923 (1978); Proctor v. State Farm Mut. Auto Ins. Co., 561 F.2d 262 (D.C. Cir.), petition for cert. flled, 
Paul Fire \& Marine Insurance Co. v. Barry, ${ }^{157}$ the first McCarran Act boycott case to reach the high court. The Barry Court held that section 3 (b) is not limited to boycotts against insurance companies and their agents.

A second question of considerable importance concerns the interrelationship of sections 2(b) and 3(b). Clearly, section 3(b) can limit the antitrust immunity that state insurance regulation can provide under section 2(b). Reading the two provisions as mutually exclusive, several courts have concluded that a broad reading of section $3(\mathrm{~b})$ would vitiate section 2(b) and congressional intentions to permit the states to regulate the business of insurance. ${ }^{158}$ The fundamentally federalist purposes of the McCarran Act suggest, however, that the two provisions should not be interpreted as inherently at odds with one another, but rather should be considered as initially complementary.

California League, Pierucci and Barry illustrate this harmonizing interpretation of sections 2(b) and 3(b). As was shown earlier, the California League decision reached the correct result that no McCarran Act immunity was appropriate, but for the wrong reasons. ${ }^{159}$ The court

46 U.S.L.W. 3375 (1977); Note, Applications of Federal Antitrust Laws to the Insurance Industry, 46 MINN. L. Rev. 1088 (1962); Note, Insurance Regulation and Antitrust Exemptions: McCarran-Ferguson, the Boycott Exception, and the Public Interest, 27 Rurgers L. REv. 140 (1973).

157. 98 S. Ct. 2923 (1978). The case involves an alleged conspiracy by four malpractice insurance companies to boycott any physician attempting to change insurers as a result of a change made in policy coverage. The defendants changed their future malpractice policies from an "occurrence" basis, covering the policyholder for claims arising from conduct while the policy was in effect, to a "claims made" basis, covering only claims arising while the policy was in effect. The Barry Court resolved a conflict in the circuit courts over the scope of section 3(b) of the McCarran Act, which makes the Sherman Act applicable to acts and agreements to "boycott, coerce, or intimidate," 15 U.S.C. $\$ 1013$ (b) (1976), in holding that the insurance companies' action constituted a "boycott" under section 3(b). The Fifth and Ninth Circuits have narrowly construed section 3(b) to cover only boycotts of insurance companies and their agents. Meicler v. Aetna Cas. \& Sur. Co., 506 F.2d 732, 734-35 (5th Cir. 1975); Addrisi v. Equitable Life Assurance Soc'y, 503 F.2d 725, 728-29 (9th Cir. 1974), cert. denied, 420 U.S. 929 (1975). Other circuits have construed section 3(b) more broadly to include any Sherman Act boycott, including boycotts of consumers. Proctor v. State Farm Mut. Auto. Ins. Co., 561 F.2d 262, $271-75$ (D.C. Cir.), petition for cert. filed, 46 U.S.L.W. 3375 (1977); Barry, 555 F.2d at 6-7; Ballard v. Blue Shield, 543 F.2d 1075, 1078 (4th Cir. 1976); cf. Monarch Life Ins. Co. v. Loyal Protective Life Ins. Co., 326 F.2d 841, 846 (2d Cir. 1963), cert. denied, 376 U.S. 952 (1964) (holding treble damages may be granted in case involving insurance company boycott). For discussions of the scope of section 3(b) and of the Barry decision in the circuit court, see.63 Cornell L. Rev. 490 (1978) and Note, Barry v. St. Paul Fire \& Marine Insurance Co.: A Re-Interpretation of the Boycott Exception to the McCarran Act, 1977 Duke L.J. 1069.

158. See, e.g., Meicler v. Aetna Cas. \& Sur. Co., 506 F.2d 732, 734 (5th Cir. 1975); Addrisi v. Equitable Life Assurance Soc'y, 503 F.2d 725, 729 (9th Cir. 1974), cert. denied, 420 U.S. 929 (1975).

159. See text accompanying notes 106-09 supra. This complementary interpretation of sections 2(b) and 3(b) is directly supported by the NAIC Memorandum of Explanation: "No twilight zone is permitted, and where any group of insurers seek to act in concert to enforce so-called 
should have reasoned that price fixing by insurers in an open-competition state did not meet section 2(b)'s standard for immunity and that section 3(b) reinforced that result. The insurers' private agreement to boycott agents who did not accept their price-fixed commission rate also fit within section 3(b)'s boycott provisions and thus complemented section 2(b). Under neither provision was a McCarran exemption appropriate.

Barry involved facts similar to those in Pierucci. In Barry, a physician plaintiff asserted that four malpractice insurance companies had conspired to boycott any physician who attempted to switch insurers as a result of a change in policy coverage. In both cases, the alleged concerted refusal to deal took place wholly beyond the states' regulatory purview. Again, section 3(b) effectively complements rather than compromises section 2(b). Judge Pettine's opinion in the Barry circuit court decision articulated the essence of this principle without specifically referring to the two provisions:

[T] here is a large difference between allowing a state to fix insurance rates without fear of antitrust sanctions and similarly insulating companies which, outside any state-permitted structure or procedure, agree among themselves that customers dissatisfied with the coverage offered by one company shall not be sold any policies by any of the other companies. ${ }^{160}$

In conclusion, McCarran Act analysis under both provisions that specifically deal with the federal antitrust laws, sections 2(b) and 3(b), can be considerably sharpened and refined if the fundamentally federalist purposes of the McCarran Act are brought to bear. A harmonizing approach, coupled with insights provided by the Parker doctrine, seems crucial to meet the new questions of McCarran Act interpretation that are confronting the courts with increasing frequency.

\section{The Special Problem of Applying the MCCARRAN-FERGUSON ACT TO INTER-INDUSTRY RESTRAINTS OF TRADE}

Beginning with the S.E.U.A. case, the McCarran-Ferguson Act has been principally applied to protect concerted rate making by insurance companies. ${ }^{161}$ In the congressional debates ${ }^{162}$ and in the majority

advisory rates, the antitrust laws will not be inapplicable." NAIC Memorandum of Explanation, reprinted in 90 CONG. REC. A4407 (1944).

160. 555 F.2d at 9.

161. See SEC v. National Sec., Inc., 393 U.S. 453, $458-59$ (1969) ("Congress was mainly concerned with the relationship between insurance ratemaking and the antitrust laws, and with the power of the States to tax insurance companies") (emphasis added). See, e.g., Ohio AFL-CIO v. Insurance Rating Bd., 451 F.2d 1178 (6th Cir. 1971), cert. denied, 409 U.S. 917 (1972); Allstate Ins. 
of cases, ${ }^{163}$ the sole concern has been intra-industry trade restraints within the business of insurance. With increasing frequency, however, the courts are being presented with the question whether to apply the McCarran-Ferguson antitrust exemption in an inter-industry context, where the trade restraints are imposed on industries other than insurance.

Restraints in the inter-industry context are of two types: one where the animus for the anticompetitive impact comes from within the insurance industry and the other where the animus comes from outside the industry. The first type of inter-industry restraint arises when actions by an insurance company adversely affect competition in another industry. It is illustrated by cases in which automobile repair shops ${ }^{164}$ and auto glass sellers ${ }^{165}$ have filed antitrust complaints charging automobile insurance companies with restraining trade in the auto repair market by using boycotts and price fixing to keep repair prices artificially low. In the health insurance field, doctors, dentists, hospitals and pharmacists, unhappy with their treatment by health insurers, have charged insurance companies with similar attempts to restrain trade in the medical, dental, hospital and pharmaceutical markets. ${ }^{166}$ More

Co. v. Lanier, 361 F.2d 870 (4th Cir.), cert. denied, 385 U.S. 930 (1966); North Little Rock Transp. Co. v. Casualty Reciprocal Exch., 181 F.2d 174 (8th Cir.), cert. denied, 340 U.S. 823 (1950).

162. Inter-industry trade restraints were never considered in any of the congressional hearings on any of the S.E.U.A.-inspired bills, probably because they did not exist at the time. The "business of insurance" had a plain and obvious meaning, with the scope of congressional consideration basically defined by the NAIC's concerns at the time. See text accompanying notes 196200 infra. Only activities between insurance companies, agents, brokers and adjusters were ever contemplated by Congress.

163. The majority of McCarran Act cases has involved solely intra-industry conduct, that is, between and among insurance companies, agents, brokers and adjusters. The cases where other businesses are allegedly subjected to restraints of trade are the exception and are generally recent. See cases cited at notes 164-66, 172-73 infra.

164. See Proctor v. State Farm Mut. Auto. Ins. Co., 561 F.2d 262 (D.C. Cir.), petition for cert. filed, 46 U.S.L.W. 3375 (1977).

165. See Hill v. National Auto Glass Co., 1971 Trade Cases (CCH) \7 73,594 (N.D. Cal. 1971); General Glass Co. v. Globe Glass \& Trim Co., 1978-1 Trade Cases (CCH) I 61,998 (N.D. IIl. 1978). See also Zelson v. Phoenix Mut. Life Ins. Co., 549 F.2d 62 (8th Cir. 1977) (securities); Battle v. Liberty Nat'l Life Ins. Co., 493 F.2d 39 (5th Cir. 1974) (funeral homes); Holly Springs Funeral Home, Inc. v. United Funeral Serv., 303 F. Supp. 128 (N.D. Miss. 1969) (funeral homes).

166. See Royal Drug Co. v. Group Life \& Health Ins. Co., 556 F.2d 1375 (5th Cir. 1977), cert. granted, 98 S. Ct. 1448 (1978) (pharmacists); Doctors, Inc. v. Blue Cross, 557 F.2d 1001 (3d Cir. 1976) (hospitals); Anderson v. Medical Serv., 1976-1 Trade Cases (CCH) I] 60,884 (E.D. Va. 1976), affd mem, 551 F.2d 304 (4th Cir. 1977) (physicians); Manasen v. California Dental Services, 424 F. Supp. 657 (N.D. Cal. 1976) (dentists); Frankford Hosp. v. Blue Cross, 417 F. Supp. 1104 (E.D. Pa. 1976) (hospitals); Nankin Hosp. v. Michigan Hosp. Serv., 361 F. Supp. 1199 (E.D. Mich. 1973) (hospitals). See also Ballard v. Blue Shield, 543 F.2d 1075 (4th Cir. 1976) (chiropractors complained of being excluded from Blue Shield coverage); Travelers Ins. Co. v. Blue Cross, 481 F.2d 80 (3d Cir. 1973) (competitor of Blue Cross challenged favorable Blue Cross contracts with hospitals); Winters v. Kansas Hosp. Serv. Ass'n, 1975-1 Trade Cases (CCH) I 
such cases appear imminent. ${ }^{167}$

The second type of inter-industry application of the McCarran exemption is presented when the providers of the goods or services covered by insurance restrain trade in their own markets through the use of insurance companies. For example, in 1974 the Antitrust Division of the United States Department of Justice refused to approve a proposed legal services insurance program, pointing out the "serious competitive risks" in the California Bar Association's control of the insurance company "for even a three year period." 168 The California Pharmaceutical Association's comparable proposal to establish a drug insurance program met the same fate two years later. ${ }^{169}$ Many years ago, local hospitals and medical societies organized their own insurance companies to pay hospital and doctor bills. ${ }^{170}$ The question that arises is whether the providers or their captive insurance ${ }^{171}$ companies are entitled to antitrust immunity under the McCarran Act. In the only case that has in-

60,140 (D. Kan. 1974) (patients without Blue Cross coverage challenged similar contracts between Blue Cross and hospitals).

Certiorari was granted in Royal Drug after this Article had been written. The case raises precisely the inter-industry "business of insurance" issue analyzed here.

167. Some form of litigation is apparently planned by doctors in Michigan and Massachusetts against the Blue Shield plan in each state because each plan pays and generally treats "participating" and "nonparticipating" physicians differently. See Medical Society to Sue Blue Shield, Am. Medical News, Oct. 31, 1977, at 1; MDs to Quit Blue Shield in Michigan, Am. Medical News, Nov. 7, 1977, at 1.

For purposes of this analysis, it is assumed that antitrust violations exist. In fact, many of these disgruntled-providers cases probably do not involve antitrust violations at all. Many health care providers believe they have a right to be paid whatever they charge for their services and do not understand that in a market economy the market determines price. Three important cases where insurer cost-containment activities have been held not to constitute antitrust violations are Anderson v. Medical Serv., 1976-1 Trade Cases (CCH) If 60,884 (E.D. Va.) affd mem., 551 F.2d 304 (4th Cir. 1977); Webster County Memorial Hosp., Inc. v. UMW Welfare \& Retirement Fund of 1950, 1976-1 Trade Cases (CCH) If 60,896 (D.C. Cir. 1976); Travelers Ins. Co. v. Blue Cross, 481 F.2d 80, 84 (3d Cir.) cert. denied, 414 U.S. 1093 (1973).

168. Letter from Thomas E. Kauper, Assistant Attorney General, Antitrust Division to Peter F. Sloss, California Lawyer's Service (Aug. 5, 1974), reprinted in 677 ANTITRUST \& TRADE REG. REP. (BNA) D-5 (1974). See generally L. Bernstein, Antitrust Considerations Involved in Prepaid Legal Plans (Dec. 8, 1973) (Antitrust Div., U.S. Dep't of Justice); B. Wilson, The Antitrust Aspects of Recent Developments in Prepaid Legal Systems (May 14, 1974) (Antitrust Div., U.S. Dep't of Justice).

169. See 787 ANTITRUSt \& TRAde Reg. Rep. (BNA) A-14 (1976).

170. See generally R. Eilers, Regulation of Blue Cross Shield Plans (1963); L. Reed, Blue Cross and Medical Service Plans (1947); A. Somers \& H. Somers, Doctors, PaTIENTS, AND HEALTH INSURANCE 291-340 (1961).

171. A recent study shows that " 44 of the 69 Blue Shield plans operating in the country had boards of directors controlled by a majority comprised of physicians or of physicians and hospital representatives." Testimony of FTC Chairman Michael Pertschuk before Subcomm. on Oversight and Investigation of House Comm. on Interstate and Foreign Commerce 3 (Mar. 21, 1978). Surprisingly, no comparable study of hospital domination of local Blue Cross plans has been performed. 
volved such a restraint, the insurance company was held exempt and the medical society was not. ${ }^{172}$ Another example of the second type of inter-industry application is where a group of providers collectively negotiate their fees with an insurer and then claim that the insurer's presence entitles them to a McCarran Act exemption. ${ }^{173}$

The McCarran Act should not be extended to inter-industry restraints of trade; antitrust immunity should instead be analyzed under the Parker doctrine. The Act by its terms applies only to the "business of insurance" and was aimed at preserving state insurance department regulation, not any and all types of state regulation. ${ }^{174}$ Moreover,

172. Ohio v. Ohio Medical Indemnity, Inc., 1976-2 Trade Cases (CCH) I 61,128 (S.D. Ohio 1976).

173. See, e.g., United States v. American Soc'y of Anesthesiologists, No. CIV 4640 (S.D.N.Y., filed Sept. 22, 1978) (anesthesiologists assert McCarran immunity); Blue Cross v. Virginia ex rel. State Corp. Comm'n, 211 Va. 180, 176 S.E.2d 439 (1970) (pharmacists-no exemption claimed).

174. In addition, some cases raise serious issues as to whether "insurance" is even involved. The issue of what constitutes "insurance" for purposes of the McCarran Act is complicated by the fact that there is no generally recognized definition of the term among insurance scholars. Professor Keeton has said: "Because the purposes for which definitions of insurance are invoked differ, no single definition will serve always, even in a single jurisdiction." KEETON 2 . The general failure of the lower courts to attempt to define "insurance" in the McCarran Act context and to determine whether it is in fact involved in a given case is difficult to explain in light of the Supreme Court's narrow construction of the term in one of its few McCarran Act decisions. In SEC v. Variable Annuity Life Ins. Co., 359 U.S. 65 (1959), the Court held that annuity contracts were not "insurance" for purposes of the McCarran Act because the putative insurer assumed "no true risk." Id. at 71. The Court also made clear that the definition of the term "insurance" in the McCarran Act is a federal question to be decided by federal courts. $I d$. at 69 . Thus, the fact that a state treats a given product as insurance or regulates it under its department of insurance does not determine whether the McCarran Act applies.

There are at least three instances where it could be argued that "insurance" for purposes of the McCarran Act is not involved. First, Blue Cross and Blue Shield plans have historically taken the position that they are not insurance but rather prepaid hospital and medical service plans. A majority of the few state courts that have considered the question have indeed held that the Blues are not insurance. See, e.g., California Physicians' Serv. v. Garrison, 28 Cal. 2d 790, 172 P.2d 4 (1946); Michigan Hosp. Serv. v. Sharpe, 339 Mich. 357, 63 N.W.2d 638 (1954); Hospital Serv. Corp. v. Pennsylvania Ins. Co., 101 R.I. 708, 227 A.2d 105 (1967). But see Cleveland Hosp. Serv. Ass'n v. Ebright, 142 Ohio St. 51, 49 N.E.2d 929 (1943). For a general analysis of health care plans as insurance, see McDavitt, Voluntary Prepayment Medical Care Plans, 1946 ABA Proc., SECTION OF INs. L. 96, 103-06. The Blues apparently take this position in order to avoid the capitalization and other requirements imposed by state insurance departments, while it is clear that the primary objective of the McCarran Act was to permit states to continue to tax and regulate the insurance business. See Prudential Ins. Co. v. Benjamin, 328 U.S. 408 (1946). For these reasons, there is a genuine question whether the Blues sell "insurance" for purposes of the McCarran Act.

Second, health maintenance organizations (HMOs) may not be insurance for McCarran Act purposes, even though some states regulate them as insurance. HMOs include insurance-like financing, but are predominiantly engaged in the business of delivering health care services. One court has held that an HMO in Washington, D.C. is not insurance. Jordan v. Group Health Ass'n, 107 F.2d 239 (D.C. Cir. 1939). See generally KeEton \& 8.2(b). Other HMOs could also be held not to be insurance for McCarran Act purposes, depending upon their organization and operation. 
analogous efforts to extend other antitrust exemptions to nontargeted markets have been denied and likewise should be denied under the McCarran Act.

\section{A. Inter-industry Trade Restraints Are Not Within the "Business of Insurance."}

A court faced with a claim of McCarran Act immunity must decide whether the anticompetitive activities at issue are within the intended reach of the Act, that is, whether such activities constitute the "business of insurance." Relying upon congressional concerns in passing the McCarran Act, the Supreme Court in National Securities established the basic guideline as to what activities are within the "business of insurance": those activities that focus on "the relationship between the insurance company and the policyholder."175

There is a discernible and commendable trend, particularly in the most recent cases, to subject the "business of insurance" inquiry to a far more searching inquiry than has been seen in the past. As the Eighth Circuit recently noted: "National Securities demands a more scrutinizing approach." 176 Nonetheless, most of the factors the courts have considered in their "business of insurance" analysis of inter-industry trade restraints are not adequate to the task.

One of the more important of these factors has been whether the activities have a substantial effect on insurance rates. In Proctor $v$. State Farm Mutual Automobile Insurance Co., ${ }^{177}$ for example, the court found that since nearly sixty-eight percent of the premium income of the automobile insurers was paid to automobile repair shops, ${ }^{178}$ the costs of the repairs had a "vital impact on [insurance] rates." "179 In partial reliance upon this factor, the court held that the insurance companies' alleged fixing of prices for repairs was within the "business of

Finally, there is a significant trend among large companies to become self-insurers and then to contract out the administration of the insurance program to conventional insurance companies. See, e.g., Wechsler, Large Firms Leaving Blue Cross for Self Insurance, 9 Bus. INs., Mar. 24,1975 , at 6, 6-7. Insurance companies that administer self-insurance programs under contract would not seem to be providing "insurance" as defined in Variable Annuity since they bear no risk. Such an interpretation is particularly appropriate since preserving state taxation of insurance was one of Congress' principal concerns in passing the McCarran Act, and one of the motivating factors in this trend is often a desire to avoid such taxation. R. EILERS \& R. CROWE, GRouP INSURANCE HANDBOOK 762 (1965).

175. 393 U.S. at 460 ; see id. at $459-64$.

176. Zelson v. Phoenix Mut. Life Ins. Co., 549 F.2d 62, 69 (8th Cir. 1977).

177. 561 F.2d 262 (D.C. Cir.), petition for cert. filed, 46 U.S.L.W. 3375 (1977).

178. 561 F.2d. at 269 n.11.

179. Id. at 270. 
insurance." The court distinguished Hill v. National Auto Glass Co. ${ }^{180}$ involving auto insurers and auto glass sellers, on the grounds that the cost of replacing windshields "presumably did not have a substantial impact on insurance rates." ${ }^{181}$ Similarly, the Third Circuit in Travelers Insurance Co. v. Blue Cross $^{182}$ relied upon the substantial impact of hospital costs on Blue Cross rates in concluding that the challenged conduct was within the "business of insurance." 183

There are several problems with reliance upon percentages such as those in Proctor. First, the percentage of revenues an insurer pays out in benefits varies greatly from company to company. For example, claim payments by health insurers as a percentage of premium income varied between types of insurers from $50.7 \%$ to $100.2 \%$ in $1975 .{ }^{184}$ Reliance upon these percentages in applying the McCarran Act to two different companies selling the same type of insurance and involved in the same trade restraint in a noninsurance industry could cause the questionable result of only one being held exempt. Second, Proctor indicates that a substantial impact exists when the cost involved accounts for sixty-eight percent or more of premium income. However, state insurance departments concerned about the solvency of insurance companies and policyholder welfare would probably consider a much smaller percentage to be substantial. For example, in 1971, Illinois, Massachusetts, Michigan and New York required Blue Cross plans in their states to maintain reserves of at least two percent, five percent, three percent and five percent, respectively, of annual premium income to assure that policyholder claims would be paid. ${ }^{185}$ Although reserve levels are not strictly comparable, they indicate that much smaller percentages than sixty-eight percent could be considered substantial by state insurance departments. As a result, trade restraints imposed by insurers on a wide scope of businesses other than those accounting for their single largest costs might be considered immune from the antitrust laws as part of the "business of insurance."

Another factor often relied upon is whether the activities at issue are closely connected to the insurer-insured relationship or are only peripheral or remote. ${ }^{186}$ The Proctor court held, first, that "the alleged

180. 1971 Trade Cases (CCH) I 73,594 (N.D. Cal. 1971).

181. 561 F.2d at 271.

182. 481 F.2d 80 (3d Cir.), cert. denied, 414 U.S. 1093 (1973).

183. 481 F.2d. at 83.

184. Mueller, Private Health Insurance in 1975: Converage, Enrollment and Financial Experience, Social Security Bull., June, 1977, at 3, 12.

185. W. Shkurti, The Costs and Financing of Health Care in Ohio: Issues and Alternatives 69 (1973) (Ohio Governor's Task Force on Health Care).

186. See, e.g., Battle v. Liberty Nat'l Life Ins. Co., 493 F.2d 39, 50 (5th Cir. 1974); Allied 
horizontal agreement to pay insureds' claim on the basis of the prevailing labor rate, as well as [the insurance companies'] supposed adherence to a common formula to compute damage estimates fits within the 'core' of the 'business of insurance." "187 As part of the determination of the amount to be paid to discharge the insurer's contractual obligation, these practices were "directly connected with the reliability, interpretation, and enforcement of the insurance contract." ${ }^{88}$ The court had more difficulty in concluding that the alleged agreements with preferred shops and the group boycott of noncooperative shops were within the business of insurance:

With respect to these . . . practices, there is at least a surface attraction to the argument . . . that what is involved here is the business of automobile repair rather than the business of insurance. Certainly, to the extent that these practices involve direct relationships between the insurance company and non-policyholders, and are less clearly connected to the terms of the contract between the insurer and the insured, they are further from the core of the business of insurance. ${ }^{189}$

The court nonetheless held that these activities were also "connected closely enough" to the contractual relationship between the companies and their policyholders and "with reliability, interpretation, and enforcement of those contracts, to qualify as the business of insurance."190

Additional factors that courts have considered in determining if conduct is within the "business of insurance" include whether the insurer is obligated or required to perform the activities, ${ }^{191}$ whether the conduct is peculiar to the insurance business, ${ }^{192}$ whether state law treats the activities as part of the business of insurance, ${ }^{193}$ whether the insurers' purposes are solely to control costs or include an intent to restrain

Financial Servs., Inc. v. Foremost Ins. Co., 418 F. Supp. 157 (D. Neb. 1976); Schwartz v. Commonwealth Land Title Ins. Co., 374 F. Supp. 564, 575 (E.D. Pa. 1974).

187. 561 F.2d at 267.

188. Id.

189. Id. at 267-68.

190. Id.

191. See, e.g., Royal Drug v. Group Life \& Health Ins. Co., 556 F.2d 1375, 1381 (5th Cir. 1977), cert. granted, 98 S. Ct. 1448 (1978).

192. See, e.g., Royal Drug v. Group Life \& Health Ins. Co., 556 F.2d 1375, 1383 (5th Cir. 1977), cert. granted, 98 S. Ct. 1448 (1978); United States v. Crocker Nat'l Corp., 1976-2 Trade Cases (CCH) \ 61,044, at 69,674 (N.D. Cal. 1976); Proctor v. State Farm Mut. Auto. Ins. Co., 406 F. Supp. 27, 30 (D.D.C. 1975), affd, 561 F.2d 262 (D.C. Cir.), petition for cert. fled, 46 U.S.L.W. 3375 (1977); American Family Life Assurance Co. v. Planned Marketing Assoc., Inc., 389 F. Supp. 1141,1145 (E.D. Va. 1974).

193. See, e.g., Pastor v. Hartford Fire Ins. Co., 1976-1 Trade Cases (CCH) If 60,783, at 68,397 (C.D. Cal. 1976). 
trade ${ }^{194}$ and whether the substance of the complaint really concerns the insurance business. ${ }^{195}$

Focusing too narrowly on such factors as the "close connection" between the challenged activity and the insurer-insured relationship, as in Proctor, has the effect of diverting attention from the key underlying statutory and policy question of whether the McCarran Act should be extended to restraints of trade imposed outside the insurance industry. Under a broader analysis, it is apparent that the phrase "business of insurance" should be limited to its plain meaning and interpreted as entirely excluding restraints of trade outside the insurance business. It seems only appropriate that the McCarran Act, which was passed to preserve state regulation of the insurance business, should be limited in its application to the insurance business. If states choose to regulate other businesses through their insurance departments, then, like other industries regulated by state agencies, their possible exemption from the antitrust laws should be determined by the standards of the Parker doctrine.

There is no indication that Congress understood the term "business of insurance" to include anything more than what its plain meaning suggests. This definition is reflected, for example, in the actions and activities described in the NAIC's memorandum explaining the Commissioners' Bill. ${ }^{196}$ The activities to be exempted included cooperative service agreements; reinsurance arrangements; the use of advisory rates, rules or plans; and the use of mandatory state approved rates or forms. The congressional debates concerning the McCarran Act discussed many of these same practices and did not at any time deal with the issue of trade restraints imposed outside the insurance industry. Indeed, one of the early House reports indicated Congress' assumption that insurance companies had no control over the costs of their benefits. ${ }^{197}$

The language of National Securities, considered in light of the legislative history of the McCarran Act, fully supports the proposition that the "business of insurance" should be confined to its ordinary meaning. The specific question addressed by the Supreme Court was "whether state laws aimed at protecting the interests of those who own securities in insurance companies are the type of laws referred to in the 1945

194. See, e.g., Proctor v. State Farm Mut. Auto. Ins. Co., 561 F.2d 262, 268 n.10 (D.C. Cir.), petition for cert. filed, 46 U.S.L.W. 3375 (1977).

195. See, e.g., Zelson v. Phoenix Mut. Life Ins. Co., 549 F.2d 62, 66, 71 (8th Cir. 1977).

196. Reprinted in 90 Cong. Rec. A4406-08 (1944).

197. H.R. ReP. No. 873, 78th Cong., 1st Sess. 8-9 (1943). 
enactment." 198 In holding that such state laws were securities regulation and not the type of state law relevant to the McCarran-Ferguson Act, the Court contrasted the types of activities that are within the "business of insurance":

Insurance companies may do many things which are subject to paramount federal regulation; only when they are engaged in the "business of insurance" does the statute apply. Certainly the fixing of rates is part of this business; that is what South-Eastern Underwriters was all about. The selling and advertising of policies, . . . and the licensing of companies and their agents, ... are also within the scope of the statute. Congress was concerned with the type of state regulation that centers around the contract of insurance, the transaction which Paul v. Virginia held was not "commerce." The relationship between insurer and insured, the type of policy which could be issued, its reliability, interpretation, and enforcement-these were the core of the "business of insurance." Undoubtedly, other activities of insurance companies relate so closely to their status as reliable insurers that they too must be placed in the same class. But whatever the exact scope of the statutory term, it is clear where the focus was-it was on the relationship between the insurance company and the policyholder. ${ }^{199}$

This language bears a striking resemblance to the kinds of activities listed in the NAIC memorandum. Certainly, the Court did not expressly indicate that the "business of insurance" must be broadly construed to cover the activities of hospitals, pharmacists, dentists and others totally outside the business of insurance. ${ }^{200}$

The National Securities Court was also faced with the application of section 2(b) of the McCarran Act to an Arizona insurance statute, ${ }^{201}$ pursuant to which the Arizona Insurance Commissioner had approved the merger of two insurance companies as not substantially reducing

198. 393 U.S. at 458.

199. Id. at 459-60.

200. Professor Keeton has described state insurance regulation as serving three main purposes:

Most measures of insurance regulation have been initiated to serve one or more of three main objectives: first, to avoid overreaching by insurers; second, to assure solidity and solvency of insurers; third, to assure that rating classifications and rates are reasonable and fair.

Regulation to avoid overreaching is principally directed at marketing practices and arrangements and has been initiated both in statutes and in judicially created doctrines.

The aim of assuring solidity and solvency is served by regulation of insurance organizations and their funds to avoid the consequences of imprudent management, and to lesser extent by an aspect of rate regulation concerned with adequacy as distinguished from reasonableness and equity.

KEETON 554-55 (footnotes omitted). The language the Supreme Court chose in describing the "business of insurance" can be read as describing no more than these customary areas of state insurance regulation.

201. ARIz. Rev. Stat. ANN. § 20-731B3 (Supp. 1969). 
the security of and service to be rendered to policyholders. ${ }^{202}$ In holding that the McCarran-Ferguson Act should be construed to allow concurrent application of the federal securities laws and the state statute, the Court stated:

In this context, all the Securities and Exchange Commission is asking is that insurance companies speak the truth when talking to their shareholders. The paramount federal interest in protecting shareholders is in this situation perfectly compatible with the paramount state interest in protecting policyholders. And the remedy the Commission seeks does not affect a matter predominantly of concern to policyholders alone; the merger is at least as important to those owning the companies' stock as it is to those holding their policies. ${ }^{203}$

The Court thus indicated that the McCarran Act was aimed at preserving state regulation of the "business of insurance" that "predominantly concern[s] policyholders alone," and that different questions arise when the activity is of equal importance to nonpolicyholders. This suggests that, in the inter-industry context, the McCarran Act should not be construed so as to preempt the federal antitrust laws, since trade restraints affecting industries outside insurance are at least of equal importance to those industries as to policyholders. ${ }^{204}$

202. 393 U.S. at 461-62.

203. Id. at 463 (emphasis added).

204. This reading of National Securities is compatible with the several cases that have held that the activities must be "peculiar" to the insurance industry to fall within the "business of insurance." See cases cited at note 192 supra. However, there will certainly be cases close enough to the margin of what could be considered the "business of insurance" to raise difficult questions. The Eighth Circuit's carefully considered opinion in Zelson v. Phoenix Mutual Life Ins. Co., 549 F.2d 62 (8th Cir. 1977), involves such a situation. An insurance agent brought an antitrust action against Phoenix Life when the insurance company terminated him for refusing to carry Phoenix Life's line of securities. The district court dismissed the action on McCarran Act grounds, and the Eighth Circuit reversed on the "business of insurance" issue, though indicating that the question presented was a close one:

The fact that plaintiff acts as an insurance agent as well as a securities broker and the fact that the activities alleged in the complaint involve in some measure the supervision or control of an insurance agent by its principal cannot ofthandedly be disregarded in assessing whether those activities constitute a part of the insurance business. At the same time, however, as plaintiff accurately points out, the alleged conduct "impinges upon the competition within the securities industry, not upon the competitive forces within the insurance industry." And, prima facie at least, the effect of an insurance agent's securities dealings on the core relationship between insurer and insured is not an obvious one.

Id. at $65-66$.

In its meticulous analysis of the relevant case law, the court distinguished Dexter v. Equitable Life Assurance Soc'y, 527 F.2d 233 (2d Cir. 1975), and Addrisi v. Equitable Life Assurance Soc'y, 503 F.2d 725 (9th Cir. 1974), cert. denied, 420 U.S. 929 (1975), two cases upholding Equitable's practice of requiring the purchase of insurance as a condition to obtaining a home loan. The Zelson court found that in those cases the anticompetitive impact was on the insurance industry:

It is apparent that Dexter and Addrisi do not support a conclusion that using insurance as a coercive lever or tying device in order to compel certain dealings in a noninsurance product or service is the business of insurance. And, precisely because such activities impinge upon competitive forces in the non-insurance market, they are less 
General principles of antitrust law and regulated industries also support this interpretation of the scope of McCarran Act immunity. These principles have been incisively synthesized in a recent Ninth Circuit decision, Foremost International Tours, Inc. v. Qantas Airways Ltd., ${ }^{205}$ involving a regulated air carrier allegedly engaging in monoplistic practices in the tour industry. The court emphasized that it was not faced with the normal situation where the anticompetitive effects were confined to the regulated industry. In such a case, the court would hesitate to interfere in areas within the authority and expertise of the regulatory agency. ${ }^{206}$ When the anticompetitive effects are not wholly within the regulated industry, however, substantial deference might not be desirable.

In this case, while the [Civil Aeronautics Board] has authority over Qantas, and arguably has the means to enforce an order against Qantas should it so choose, in lacking authority over all the parties, it cannot make the accommodations and effect the compromises which are the hallmark of agency regulation. It may well lack the means to deal with the total problem. But more importantly, the regulatory agency here also lacks the expertise and the incentive (一after all it is not its industry $\rightarrow$ to act on an inter-industry problem. There is the danger that in cases such as this the regulatory agency might favor its own regulated industry at the expense of non-regulated commerce, or at the very least, might consider the resolution of such matters to be of a less pressing priority. ${ }^{207}$

As a result, the court held that the federal antitrust laws were not preempted by the $C A B$ when the anticompetitive effects were outside the regulated industry. A regulatory agency's approval of certain actions cannot confer antitrust immunity unless the primary anticompetitive effect those actions may have is limited to the industry in question. ${ }^{208}$

readily characterizable as insurance activities than are arrangements of the DexterAddrisi type.

549 F.2d. at 67 . Emphasizing that the challenged activities restrained the securities and not the insurance business, the court held that there was insufficient certainty that the "business of insurance" was involved to warrant dismissal on McCarran Act grounds.

205. 525 F.2d 281 (9th Cir. 1975), cert. denied, 429 U.S. 816 (1976); accord, ITT Corp. v. Gen. Tel. \& Elec. Corp., 1978-1 Trade Cases (CCH) I 61,913 (D. Hawaii 1978).

206. 525 F.2d at 284.

207. Id. at 285 (emphasis added). See also City of Lafayette v. Louisiana, 98 S.Ct. 1123, 1137 (1978) (expressing analogous concerns that "parochial interests may undermine national economic policy favoring a market system").

208. 525 F.2d. at 286. The Supreme Court's recent decision in Cantor v. Detroit Edison Co., 428 U.S. 579 (1976), fully supports the Ninth Circuit's conclusion and the proposition advanced here. Cantor involved a similar issue of applying the federal antitrust laws to a highly regulated industry where the activity in question adversely affected an unregulated segment of the economy. The defendant electric utility was charged with using its monopoly power in distributing electricity to restrain trade in the sale of light bulbs. Notwithstanding that the Michigan Public Service Commission "pervasively regulated" the distribution of electricity and had "complete power and 
Similarly, state insurance departments have the authority, expertise and incentives to regulate only the insurance business. In passing the McCarran Act, Congress did not recognize any special ability of state insurance departments to regulate the auto repair business, or hospitals, dentists, doctors and lawyers. Indeed, as suggested in Qantas Airways, there is a real danger that state insurance departments not only lack the authority and expertise to regulate other businesses, but that they are also apt to favor their industry at the expense of others. Trade restraints affecting other businesses, for example, might be viewed favorably if they add to the stability and financial security of insurance companies. Nor did Congress at any time intimate that the special needs of insurance transcended the insurance business and must include the ability to restrain trade in other sectors of the economy.

Under this more limited interpretation of the business of insurance, trade restraints whose anticompetitive effects impact on noninsurance businesses would be beyond the reach of the McCarran Act, regardless of whether the anticompetitive animus came from within or without the insurance industry. ${ }^{209}$ Cost containment efforts by insurance companies, as well as activities by providers of an insured good or service group to influence their reimbursement by insurance companies, would thus be subject to antitrust scrutiny. ${ }^{210}$ Moreover, the per-

jurisdiction to regulate all public utilities in the state," a six to three Supreme Court majority held that the utility's conduct was subject to the federal antitrust laws. In an opinion joined by five justices, the Court stated:

There is no logical inconsistency between requiring such a firm to meet regulatory criteria insofar as it is exercising its natural monopoly powers and also to comply with antitrust standards to the extent that it engages in business activity in competitive areas of the economy.

Id. at 596 (footnote omitted).

209. This interpretation is further supported by the Supreme Court's insistence in other contexts on focusing on the industry where the anticompetitive effects have their impact and on refusing to permit exemptions in one area to be extended to other businesses. Thus, for example, efforts to extend a lawful patent monopoly to other products by tie-ins or by prohibiting the sale of competitive products have been held illegal. See, e.g., International Salt Co. v. United States, 332 U.S. 392 (1947); McCullough v. Kammerer Corp., 166 F.2d 759 (9th Cir. 1948).

In affirming the criminal conviction of the American Medical Association for preventing an HMO from operating in Washington, D.C., the Supreme Court held that it was irrelevant if physicians were entitled to a "learned profession" exemption since the trade restraint did not impact on physicians but on the HMO's business: "As the Court of Appeals properly remarked, the calling or occupation of the individual physicians charged as defendants is immaterial if the purpose and effect of their conspiracy was such obstruction and restraint of the business of Group Health." American Medical Ass'n v. United States, 317 U.S. 519, 528 (1943). Also, in Allen Bradley Co. v. Local 3, IBEW, 325 U.S. 797 (1945), the Court held that a union conspiracy to restrain trade in the product manufactured by its members' employers was beyond the labor union exemption.

210. For the kinds of collective action that would not violate the antitrust laws, see Third Party Prepaid Prescription Programs: Hearings Before Subcomm, on Environmental Problems Af. 
sons who could claim a McCarran Act exemption would be limited, as section 2(a) would seem to require, to persons engaged in the business of insurance. ${ }^{211}$

\section{B. Inter-industry Trade Restraints Are Not Subject to the Requisite State Insurance Regulation.}

In addition to the preceeding "business of insurance" analysis, section 2(b)'s requirements as to the nature of state regulation necessary to provide McCarran Act antitrust immunity also have important implications for the problem of inter-industry restraints of trade. When section 2(b) is applied outside of the regulated rating bureau setting in general, and to restraints of trade involving businesses other than insurance in particular, the previously developed two-stage legal analysis is required. First, would the pertinent state regulatory statutes be "invalidated, impaired, or superseded" if the federal antitrust laws were applicable? Second, does the department of insurance have specific regulatory authority, and what result does the Parker doctrine suggest?212

The district court decision in Proctor $^{213}$ provides an excellent example of a court's failure to make such an analysis, resulting in a grant of McCarran Act immunity without the necessary type of state regulation. Proctor involved claims by automobile repair shop owners that five insurance companies had violated the antitrust laws in various ways, including an attempt to fix auto repair prices. Relying on dicta from California League, ${ }^{214}$ the court held after little analysis that sec-

fecting Small Business of House Select Comm. on Small Business, pt. 2, 92nd Cong. 1st Sess. 227. (1971) (remarks of Bruce B. Wilson).

211. A few courts have recently extended McCarran Act immunity to persons wholly outside the business of insurance. The first court to do so was the district court in Royal Drug Co. v. Group Life \& Health Ins. Co., 415 F. Supp. 343, 350 (W.D. Tex. 1976), rev'd on other grounds, 556 F.2d 1375 (5th Cir. 1977), cert. granted, 98 S. Ct. 1448 (1978), which held that participating pharmacists are entitled to McCarran Act immunity. But see Pastor v. Hartford Fire Ins. Co., 1976-1 Trade Cases (CCH) \ 60,783, at 68,398 (C.D. Cal. 1976) (Los Angeles County Medical Society not exempt).

212. If, for example, a state has entrusted its insurance department with a regulatory mandate over other businesses, as Pennsylvania appears to have done with respect to Blue Cross and hospitals, the Parker doctrine would be fully applicable to provide antitrust immunity when warranted. See, e.g., Travelers Ins. Co. v. Blue Cross, 481 F.2d 80 (3d Cir. 1973); Frankford Hosp. v. Blue Cross, 417 F. Supp. 1104 (E.D. Pa. 1976), cert. denied, 434 U.S. 860 (1977). Pennsylvania's long-standing policy regarding Blue Cross and hospitals is so clearly and affirmatively expressed that it would seem to readily satisfy the Supreme Court's standards for Parker immunity as enunciated most recently in Bates v. State Bar of Ariz., 433 U.S. 351, 359-63 (1977) (unanimous ruling on Parker immunity). See generally S. LAW, Blue Cross: What Went Wrong (2d ed. 1976).

213. 406 F. Supp. 27 (D.D.C. 1975), affd, 556 F.2d 262 (D.C. Cir. 1977), petition for cert. filed, 46 U.S.L.W. 3375 (1978). The lower court's "regulation" holding was not appealed.

214. The California League court stated that "a State regulates the business of insurance 
tion 2(b)'s "regulation" requirement had been satisfied. The best statute the court could muster in support of its ruling, however, was the Pennsylvania Motor Vehicle Physical Damage Appraiser Act, which the court stated "is a regulatory scheme closely related to the practices at issue in this case."215 Yet as the title of the Act suggests and its actual provisions confirm, the Act merely provides for the licensing and regulation of persons who appraise physical damages to cars. It neither deals with concerted actions by insurance companies to fix the prices paid for auto repairs nor in any way establishs a scheme for administrative supervision of such practices. The only other Pennsylvania statute cited by the court is one that provides the insurance commissioner with the authority to require insurers to settle claims with policyholders fairly ${ }^{216}$ Since the alleged price-fixing scheme should result in the policyholders' repair bills being paid in full, there would be no unfairness problem for the policyholder. Indeed, the policyholder should benefit from a price-fixing conspiracy that kept auto repair costs low since lower insurance premiums should result. In analyzing the case under Virginia law, the court cited a similar unfair settlement practices statute and the state's supervised rating bureau statute for auto insurance, neither of which addressed the anticompetitive activity involved. The statutes cited by the district court in Proctor do not even satisy the California League standard, since they do not generally proscribe, permit or authorize the conduct at issue. The federal antitrust laws complement the policy of both states by proscribing insurer cartel price fixing of auto repair shop rates; they do not "invalidate, impair, or supersede" the state regulatory schemes. The state regulation involved neither specifically regulates the anticompetitive practices at issue nor constitutes a "state policy to displace competition with regulation" in auto repair markets. ${ }^{217}$ A Parker analysis further underscores the conclusion that section 2(b) should not have been satisfied by these statutes, since they do not reflect an independent state regulatory interest over concerted auto repair shop price setting by insurers. ${ }^{218}$

within the meaning of $\S 1012$ (b) when a State statute generally proscribes . . . or permits or authorizes certain conduct on the part of insurance companies." $175 \mathrm{~F}$. Supp. at 860.

215. 406 F. Supp. at 31 . The Act is presently codified at PA. STAT. ANN. tit. $63, \S 8851-863$ (Purdon Supp. 1978).

216. The court cited PA. Stat. AnN. tit. $40 \S 1155$ (Purdon 1971), 406 F. Supp. at 31, although it probably intended to cite section 1153. Both sections, however, were repealed in 1974. The new statute provides the Commissioner with essentially the same power. PA. STAT. ANN. tit. 40, § 1171.7 (Purdon Supp. 1978).

217. City of Lafayette v. Louisiana Power \& Light Co., 98 S.Ct. 1123, 1137 (1978).

218. Similarly, in Cantor v. Detroit Edison Co., 428 U.S. 579 (1976), the Court was unwilling to grant immunity to Detroit Edison's light bulb exchange program despite the fact that the program had been approved by the state. The Court apparently felt that the state had not demon- 
State insurance provisions that provide for the approval of policy forms should also be held insufficient to satisfy section 2(b). In Royal Drug Co. v. Group Life \& Health Insurance Co., ${ }^{219}$ involving a challenge to Texas Blue Shield's participating pharmacy contracts, the district court relied upon such a provision, ${ }^{220}$ upon an unfair competition $1 \mathrm{aw}^{221}$ and upon general antitrust law ${ }^{222}$ to find that section 2(b) was satisfied. ${ }^{223}$ Policy approval provisions are designed to protect policyholders from insurance policies, for example, that are "unjust, unfair, inequitable, misleading, deceptive or contrary to law or to the public policy of this state."224 Such provisions regulate only the insurer-insured relationship and should not be read as providing state insurance departments with the exclusive power to protect noninsurance businesses from anticompetitive practices. Again, application of the federal antitrust laws would not "invalidate, impair, or supersede" this type of state regulation, particularly as that standard was applied in National Securities. ${ }^{225}$ The Supreme Court's treatment of a similar problem in the Cantor decision is also illuminating:

Unquestionably there are examples of economic regulation in which the very purpose of the government control is to avoid the consequences of unrestrained competition. Agricultural marketing programs, such as that involved in Parker, were of that character. But all economic regulation does not necessarily suppress competition. On the contrary, public utility regulation typically assumes that the private firm is a natural monopoly and that public controls are necessary to protect the consumer from exploitation. There is no logical inconsistency between requiring such a firm to meet regulatory criteria insofar as it is exercising its natural monopoly powers and also to comply with antitrust standards to the extent that it engages in business activity in competitive areas of the economy. ${ }^{226}$

The Texas policy approval provision hardly seems to be the type of economic regulation whose central purpose is to avoid the consequences of unrestrained competition in the pharmacy market. As state insurance regulation moves further away from regulating the insurerinsured relationship, the standard for satisfying section 2(b) should in-

strated an intent to regulate or control the "essentially unregulated . . . market for electric light bulbs." Id. at 595 .

219. 415 F. Supp. 343 (W.D. Tex. 1976), rev'd on other grounds, 556 F.2d 1375 (5th Cir. 1977), cert. granted, 98 S. Ct. 1448 (1978).

220. Tex. Ins. Code ANN. art. 3.42 (Vernon Supp. 1978).

221. Id. art. 21.21.

222. TeX. Bus. \& Com. Code ANN. tit. 2, § 15.04 (Vernon 1968).

223. 415 F. Supp. at 348.

224. TeX. Ins. Code ANN. art. 3.42(f)(2) (Vernon Supp. 1978).

225. See text accompanying notes $93-94$ supra.

226. 428 U.S. at 595-96 (footnotes omitted). 
crease proportionately. In peripheral areas such as anticompetitive conduct by insurers in noninsurance markets, where state insurance departments' authority, expertise and incentives are ambiguous, section 2(b) should be interpreted to require considerably more than policy approval provisions.

An informative contrast is provided by Frankford Hospital v. Blue Cross, ${ }^{227}$ in which Philadelphia Blue Cross' reimbursement policy was challenged for paying hospitals too little. Blue Cross' contractual relationships and reimbursement methods were both subject to the extensive regulatory authority of the Pennsylvania Insurance Department. Moreover, beginning in 1967, the Department had required Blue Cross to reimburse hospitals in a manner that excluded certain costs and resulted in Blue Cross paying hospitals less than they would if all costs were included. The court carefully traced the origin of this affirmative policy by the Insurance Department ${ }^{228}$ and could have properly concluded that Parker immunity applied. As in Bates, the genesis of the hospital reimbursement policy came from the state. Furthermore, the state statutes in Frankford Hospital specifically empowered the insurance department to regulate the relationship of Blue Cross with hospitals, deliberately adopting a policy that the hospital services market required this type of regulation. Unlike Cantor, state policy on reimbursing hospitals was far from neutral and illustrates a fundamentally different type of regulation than that present in Royal Drug.

This suggested reading of section 2(b) would also exclude trade restraints in the inter-industry context where the anticompetitive animus comes from outside the insurance industry. In such cases, both the perpetrators of the restraint and the impact of the restraint are outside the insurance industry. In almost every instance, state insurance departments have no real authority to regulate the persons responsible for the antitrust violations. For example, the California Department of Insurance would not have had adequate authority over the California Bar Association or the California Pharmaceutical Association if they had gone ahead and launched their anticompetitive legal services or drug

227. 417 F. Supp. 1104 (E.D. Pa. 1976). Parker v. Brown, not the McCarran Act, should apply because the trade restrained was alleged to be the horizontal market and thus was outside the "business of insurance" under the analysis in part A of this Article. See text accompanying notes 175-211 supra. The Frankford case is nonetheless useful to illustrate the type of regulating scheme that section 2 (b) otherwise requires.

228. 417 F. Supp. at 1106-08. The court also relied upon the Third Circuit's ruling in Travelers Ins. Co. v. Blue Cross, 481 F.2d 80 (1973), which dealt at length with the specific statutes involved and the policies adopted by the Insurance Department. 
insurance plans. ${ }^{229}$ Nor would state insurance departments have any authority over the American Society of Anesthesiologists if they indeed were fixing anesthesiologists' fees with insurance companies. ${ }^{230}$ As the Ninth Circuit observed in Qantas Airways with regard to the CAB:

While the $C A B$ has authority over [the carrier], and arguably has the means to enforce an order against [the carrier] should it so choose, in lacking authority over all the parties, it cannot make the accommodations and effect the compromises which are the hallmark of agency regulation. ${ }^{231}$

Therefore, a careful analysis of the state insurance department regulations that are arguably applicable to inter-industry restraints of trade usually will show that the state's interests are confined to protecting policyholders and do not express any state policy to suppress competition in noninsurance markets. In such cases, the nature of the regulations provides additional support for concluding that the McCarran Act should not apply.

\section{The McCarran Act Should Not Be Extended to Inter-industry Trade Restraints By Analogy to Other Antitrust Exemptions}

Congress presumably did not intend the McCarran Act and the exemption from the antitrust laws it created to be interpreted in a vacuum. Other antitrust exemptions have been construed by the courts to reject attempts by persons outside the scope of the exemption to shield their anticompetitive activities though acting in concert with exempt entities. These interpretations also support the conclusion that the McCarran Act should not be extended to inter-industry trade restraints.

In the labor and agricultural cooperative areas, it is well settled that an exempt entity loses its exemption if it combines with a nonexempt entity to engage in antitrust violations. For example, the courts

229. See 787 AntITRUST \& TRADE REg. ReP. (BNA) A-14 (1976). See text accompanying note 168 supra.

230. Cf. United States v. American Soc'y of Anesthesiologists, No. CIV 4640 (S.D.N.Y., filed Sept. 22, 1978) (anesthesiologists assert McCarran immunity).

231. 525 F.2d at 285. Construing the "business of insurance" to include actions that impact within the insurance industry is consistent with the Supreme Court's construction of the related section 2(b) phrase "regulated by state law." In FTC v. Travelers Health Ass'n, 362 U.S. 293 (1960), the Court held that a Nebraska law purporting to regulate out-of-state advertising by Nebraska insurance companies was not adequate state regulation to preempt the Federal Trade Commission Act in other states. Id. at 302. The inadequacy in Travelers Health stemmed from the geographic distance between consumers and the state attempting to protect those consumers and from possible commerce clause problems. This decision suggests that the Court would be similarly concerned about inadequate protection of the public that results when insurance company actions impact outside of the industry. 
have consistently held that when a labor union combines or conspires with or aids a nonlabor group to monopolize or restrain trade in its product market the union loses its exemption from the antitrust laws. ${ }^{232}$ This is true even though the objective of the union's activity may be valid, for example, to secure legitimate benefits for its members. Similarly, in United States v. Borden Co., ${ }^{233}$ a Capper-Volstead agricultural cooperative exemption was lost due to a conspiracy between a milk producers' co-op, a milk distributors' trade association and other nonexempt entities to maintain artificial and noncompetitive prices for milk in Chicago. The Supreme Court stated:

The right of these agricultural producers thus to unite in preparing for market and in marketing their products, and to make the contracts which are necessary for the collaboration, cannot be deemed to authorize any combination or conspiracy with other persons in restraint of trade that these producers may see fit to devise. ${ }^{234}$

These principles have been applied in a McCarran Act context. In Hill v. National Auto Glass Co., ${ }^{235}$ Allstate Insurance engaged in the practice of sending property damage claimants to selected auto glass installers as part of an alleged conspiracy to fix prices, allocate business and boycott certain installers in the auto glass industry. Relying upon National Securities, the court rejected Allstate's motion to dismiss on McCarran grounds: "Congress at no time indicated an intent to give insurance companies carte blanche to operate in concert with noninsurance companies. The McCarran Act will be narrowly construed by this Court to extend only so far as the problem it sought to solve."236

Antitrust immunity has also been denied in the labor area on the grounds that a union formed and dominated by a group of employers through their trade association was not a bona fide union. ${ }^{237}$ In the one case that has expressly dealt with the issue of a seller-controlled insurance company, the court applied the means-ends doctrine of conspiracy

232. See, e.g., Ramsey v. UMW, 401 U.S. 302 (1971); Local 189, Amalgamated Meat Cutters \& Butcher Workmen v. Jewel Tea Co., 381 U.S. 676 (1965); UMW v. Pennington, 381 U.S. 657 (1965); Allen Bradley Co. v. Local 3, IBEW, 325 U.S. 797 (1945).

233. 308 U.S. 188 (1939).

234. Id. at 204-05; accord, Case-Swayne Co. v. Sunkist Growers, Inc., 389 U.S. 384 (1967); Maryland \& Va. Milk Producers Ass'n, v. United States, 362 U.S. 458 (1960).

235. 1971 Trade Cases (CCH) I 73,594 (N.D. Cal. 1971).

236. Id. at 90,459. See also Battle v. Liberty Nat'l Life Ins. Co., 493 F.2d 39 (5th Cir. 1974); Center Ins. Agency, Inc. v. Byers, 1976-1 Trade Cases (CCH) \| 60,940 (N.D. Ill. 1976).

237. Carpenters Dist. Council v. United Contractors Ass'n, 484 F.2d 119, 121 (6th Cir. 1973); accord, International Ass'n of Heat \& Frost Insulators \& Asbestos Workers v. United Contractors Ass'n, 483 F.2d 384 (3rd Cir. 1973); cf. United States v. Sealy, Inc., 388 U.S. 350 (1967) (dealing with the issue of whether vertical or horizontal market division was involved, and standing for the proposition that competitors cannot escape antitrust liability for anticompetitive conduct they attempt to disguise behind a corporate "front" that they control). 
law $^{238}$ to deny McCarran Act immunity to the sellers while granting immunity to the insurance company itself. ${ }^{239}$ The Ohio State Medical Association was charged with using its wholly-owned Blue Shield subsidiary to fix prices and otherwise restrain trade for physicians' goods and services. The court reasoned:

For purposes of this decision, the Court assumes that OMI's purpose in adopting the claim's [sic] settlement procedures it follows is to monopolize physician fees and the costs of physicians' goods and services. This ulterior purpose is not a part of "the business of insurance." Nonetheless, the means of accomplishing that end are part of the "business of insurance."240

These cases illustrate the kind of careful scrutiny that is required before antitrust exemptions are extended to persons and activities that were not contemplated by Congress. Their basic principles are applicable in construing the scope of McCarran Act immunity. As previously indicated, the basic purposes of Congress in passing the McCarran Act were to preserve state regulation and taxation of insurance without emasculating the antitrust laws. Both these objectives would be contradicted by reading the McCarran Act as applying to inter-industry trade restraints, especially when the anticompetitive animus comes from outside the insurance industry. State insurance departments have neither the authority nor expertise to regulate such practices. Statutes that grant an insurance department authority to approve policy forms, for example, only slightly touch these anticompetitive practices and should be held insufficient to satisfy section 2(b)'s "to the extent . . . regulated by state law" requirement for McCarran immunity. Assuming that the "business of insurance" is involved, section 2(b) requires no less than a statutory scheme comparable to the supervised rate-making statutes for insurance company rates. From a doctrinal point of view, however, antitrust analysis and congressional intentions are best served by construing activities that result in trade restraints outside the insurance field as not being within the "business of insurance." Then, to the extent state insurance departments have been granted specific authority to regulate inter-industry restraints of trade, the availability of an exemption from the antitrust laws would be determined accord-

238. The court's differentiation between insurance "means" and noninsurance "ends" is quite consistent with a fundamental principle of conspiracy law established by the Supreme Court in Duplex Printing Press Co. v. Deering, 254 U.S. 443 (1921): "If the purpose be unlawful it may not be carried out even by means that otherwise would be legal; and although the purpose be lawful, it may not be carried out by criminal or unlawful means." Id. at 465-66. 1976).

239. Ohio v. Ohio Med. Indemnity, Inc., 1976-2 Trade Cases (CCH) \ 61,128 (S.D. Ohio

240. Id. at 70,112 . 
ing to the principles of the Parker doctrine. ${ }^{241}$

\section{CONCLUSION}

This Article began with the observation that the scope of the McCarran Act's antitrust exemption for insurance has never been authoritatively resolved by the Supreme Court of the United States. The Court's recent Barry decision and grant of certiorari in Royal Drug may well indicate that the present Court is inclined to begin settling the many unanswered questions surrounding this important antitrust exemption.

An analysis of the McCarran Act's genesis and legislative history reveals that not only is this source richer than many had previously thought, but also indicates that the Act implements fundamentally federalist, congressional purposes. Congress was primarily concerned with preserving state taxation and regulation of insurance from constitutional annihilation and did not intend to emasculate the federal antitrust laws. Contrary to the thrust of some lower court decisions, Congress never intended state regulation to be exclusive if federal and state authority could be accommodated concurrently. Preserving state regulation under principles of federalism requires federal preemption under the McCarran Act only when the concurrent authority of both sovereigns is irreconcilable.

Legislative intentions underlying the McCarran Act therefore deserve a searching inquiry before federal antitrust immunity under section 2(b) should be granted. The precise standards to be applied include the threshold requirements that insurance is involved, that the activities are within the "business of insurance" and that the applicable state laws constitute insurance regulation. Assuming the threshold conditions are met, a two-stage test for applying section 2(b) is appropriate. First, one must determine whether the federal antitrust laws "invalidate, impair, or supersede" state insurance regulation of the anticompetitive activities in question, as that standard has been interpreted by the Supreme Court in National Securities. If not, no exemption should be

241. The Parker doctrine provides a basis for dealing with an underlying concern that undoubtedly influenced the court in Ohio Medical Indemnity and generally influences courts in antitrust treble damage litigation, namely, the threat of treble damage liability that conceivably could bankrupt an insurance company, even though the insurance company was not the principal actor. In Ohio Medical Indemnity the court immunized the insurance company but not the party alleged to be responsible for the restraint of trade. Six justices in the Cantor decision indicated that a fairness defense may be appropriate in certain Parker situations. 428 U.S. at 592-98, 603, 614 (opinions of Chief Justice Burger and Justices Stevens and Blackmun). Justice Blackmun indicated that fairness may provide a defense to damages but not to injunctive relief. $I d$. at $614 \mathrm{n} .6$ (Blackmun, J., concurring). 
granted. Second, if federal law does "invalidate, impair, or supersede" state insurance regulation, then the federal antitrust laws are inapplicable only to the extent that the anticompetitive conduct is regulated by state insurance laws. This Article does not attempt to analyze all of the issues involved in applying this second test. Instead, the often-neglected "to the extent" language of section 2(b) was analyzed and was found to embody the congressional intent that there exist specific regulatory authority over the conduct at issue before an exemption may be granted. Moreover, the standards of the Parker doctrine should also be considered, since the proviso clause could be held to codify the Parker doctrine and, at the very least, is directly analogous.

Finally, the Article analyzes the question of whether the McCarran Act should be extended to inter-industry restraints of trade. It concludes that the Act's antitrust exemption should not be extended to restraints of trade having effects outside the insurance business. Congress never intended persons outside the insurance business to use insurance companies and the McCarran Act as tools for creating monopolies or cartels in their own businesses without triggering antitrust liability. Nor did Congress ever intend to permit insurance companies to create monopolies or cartels to restrain doctors, dentists, hospitals, lawyers, auto repair shops or any other noninsurance industry with which insurers necessarily do business. Insurers should be expected to aggressively control and minimize costs, but they should not use methods which violate the antitrust laws and obtain immunity by an unwarranted extension of the McCarran-Ferguson Act. When industries other than insurance are subjected to antitrust violations purportedly regulated by state law, claims of antitrust immunity should not be determined by the McCarran Act but by the Parker doctrine. 


\section{APPENDIX A}

The McCarran-Ferguson Act, 15 U.S.C. $\S \S 1011-1015$ (1976) (originally enacted as Act of Mar. 9, 1945, ch. 20, 59 Stat. 33), as amended by Act of July 25, 1947, ch. 326, 61 Stat. 448, and Act of Aug. 1, 1956, ch. 852, § 4, 70 Stat. 908.

Sec. 1. Congress hereby declares that the continued regulation and taxation by the several States of the business of insurance is in the public interest, and that silence on the part of the Congress shall not be construed to impose any barrier to the regulation or taxation of such business by the several States.

Sec. 2. (a) The business of insurance, and every person engaged therein, shall be subject to the laws of the several States which relate to the regulation or taxation of such business.

(b) No Act of Congress shall be construed to invalidate, impair, or supersede any law enacted by any State for the purpose of regulating the business of insurance, or which imposes a fee or tax upon such business, unless such Act specifically relates to the business of insurance: Provided, That after June 30, 1948, the Act of July 2, 1890, as amended, known as the Sherman Act, and the Act of October 15, 1914, as amended, known as the Clayton Act, and the Act of September 26, 1914, known as the Federal Trade Commission Act, as amended, shall be applicable to the business of insurance to the extent that such business is not regulated by State Law.

Sec. 3. (a) Until June 30, 1948, the Act of July 2, 1890, as amended, known as the Sherman Act, and the Act of October 14, 1914, as amended, known as the Clayton Act, and the Act of September 26, 1914, known as the Federal Trade Commission Act, as amended, and the Act of June 19, 1936, known as the Robinson-Patman Antidiscrimination Act, shall not apply to the business of insurance or to acts in the conduct thereof.

(b) Nothing contained in this Act shall render the said Sherman Act inapplicable to any agreement to boycott, coerce, or intimidate, or act of boycott, coercion, or intimidation.

Sec. 4. Nothing contained in this Act shall be construed to affect in any manner the application to the business of insurance of the Act of July 5, 1935, as amended, known as the National Labor Relations Act, or the Act of June 25, 1938, as amended, known as the Fair Labor Standards Act of 1938, or the Act of June 5, 1920, known as the Merchant Marine Act, 1920.

Sec. 5. As used in this Act, the term "State" includes the several States, Alaska, Hawaii, Puerto Rico, Guam, and the District of Columbia.

Sec. 6. If any provision of this Act, or the application of such provision to any person or circumstances, shall be held invalid, the remainder of the Act, and the application of such provision to persons or circumstances other than those as to which it is held invalid, shall not be affected.

\section{APPENDIX B}

The Original Text of the McCarran-Ferguson Bill, S. 340, 79th Cong. 1st Sess., 91 CoNG. REC. 330 (1945).

\section{A BILL}

To express the intent of the Congress with reference to the regulation of the business of insurance.

Be it enacted by the Senate and House of Representatives of the United States of America in Congress assembled, That the Congress hereby declares that the continued regulation and taxation by the several States of the business of insurance is in the public interest, and that silence on the part of the Congress shall not be construed to impose any barrier to the regulation or taxation of such business by the several States. 
Sec. 2. (a) The business of insurance, and every person engaged therein, shall be subject to the laws of the several States which relate to the regulation or taxation of such business.

(b) No Act of Congress shall be construed to invalidate, impair, or supersede any law enacted by any State for the purpose of regulating the business of insurance, or which imposes a fee or tax upon such business, unless such Act specifically so provides.

Sec. 3. Nothing contained in the Act of September 26,1914, known as the Federal Trade Commission Act, as amended, or the Act of June 19, 1936, known as the Robinson-Patman Antidiscrimination Act, shall apply to the business of insurance or to acts in the conduct thereof.

Sec. 4. (a) For the purpose of enabling adjustments to be made and legislation to be adopted by the several States and Congress, until June 1, 1947, the Act of July 2, 1890, as amended, known as the Sherman Act, shall not apply to the business of insurance, or to acts in the conduct of such business, and until January 1, 1948, the Act of October 15, 1914, as amended, known as the Clayton Act, shall not apply to such business or to acts in the conduct of that business.

(b) Nothing contained in this section shall render the said Sherman Act inapplicable to any act of boycott, coercion, or intimidation.

Sec. 5. Nothing contained in this Act shall be construed to affect in any manner the application to the business of insurance of the Act of July 5, 1935, as amended, known as the National Labor Relations Act, or the Act of June 25, 1938, as amended, known as the Fair Labor Standards Act of 1938.

Sec. 6. As used in this Act, the term "State" includes the several States, Alaska, Hawaii, Puerto Rico, and the District of Columbia.

Sec. 7. If any provision of this Act, or the application of such provisions to any person or circumstances, shall be held invalid, the remainder of the Act, and the application of such provision to persons or circumstances other than those as to which it is held invalid, shall not be affected. 
